\title{
PREFERENCE PARAMETERS AND \\ BEHAVIORAL HETEROGENEITY: AN \\ EXPERIMENTAL APPROACH IN THE \\ HEALTH AND RETIREMENT SURVEY
}

Robert B. Barsky

Miles S. Kimball

F. Thomas Juster

Matthew D. Shapiro

Working Paper No. 5213

\author{
NATIONAL BUREAU OF ECONOMIC RESEARCH \\ 1050 Massachusetts Avenue \\ Cambridge, MA 02138 \\ August 1995
}

This research is supported by a grant from the National Institute of Aging. Carlos Quintanilla and Lisa Sanchez provided excellent research assistance. This revision is based on the gamma revision of the Health and Retirement Survey Wave I tape. This paper is part of NBER's research programs in Asset Pricing, Economic Fluctuations, and Monetary Economics. Any opinions expressed are those of the authors and not those of the National Bureau of Economic Research.

() 1995 by Robert B. Barsky, Miles S. Kimball, F. Thomas Juster and Matthew D. Shapiro. All rights reserved. Short sections of text, not to exceed two paragraphs, may be quoted without explicit permission provided that full credit, including $\odot$ notice, is given to the source. 


\title{
PREFERENCE PARAMETERS AND \\ BEHAVIORAL HETEROGENEITY: AN \\ EXPERIMENTAL APPROACH IN THE \\ HEALTH AND RETIREMENT SURVEY
}

\begin{abstract}
Individuals' preferences underlying most economic behavior are likely to display substantial heterogeneity. This paper reports on direct measures of preference parameters relating to risk tolerance, time preference, and intertemporal substitution. These experimental measures are based on survey respondents' choices in hypothetical situations. The questions are constructed with as little departure from the theorist's concept of the underlying parameter as possible.

The individual measures of preference parameters display substantial heterogeneity. The majority of respondents fall into the least risk-tolerant group, but a substantial minority display higher risk tolerance. The individual measures of intertemporal substitution and time preference also display substantial heterogeneity. The mean risk tolerance is 0.25 ; the mean elasticity of intertemporal substitution is $\mathbf{0 . 2}$. Estimated risk tolerance and the elasticity of intertemporal substitution are essentially uncorrelated across individuals.

Because the risk tolerance measure is obtained as part of the main questionnaire of a large survey, it can be related to a number of economic behaviors. Measured risk tolerance is positively related to a number of risky behaviors, including smoking, drinking, failing to have insurance, and holding stocks rather than Treasury bills. Although measured risk tolerance explains only a small fraction of the variation of the studied behaviors, these estimates provide evidence about the validity and usefulness of the measures of preference parameters.
\end{abstract}

Robert B. Barsky

Survey Research Center and

Department of Economics

University of Michigan

Ann Arbor, MI 48109

and NBER

F. Thomas Juster

Survey Research Center and

Department of Economics

University of Michigan

Ann Arbor, MI 48109
Miles S. Kimball

Survey Research Center and

Department of Economics

University of Michigan

Ann Arbor, MI 48109

and NBER

Matthew D. Shapiro

Survey Research Center and

Department of Economics

University of Michigan

Ann Arbor, MI 48109

and NBER 


\section{Introduction}

This paper describes the results of an experimental attempt to elicit individual preference parameters by means of direct questions closely derived from economic theory, and to study the behavioral implications of heterogeneity in the measured parameters across individuals. Participants in the Health and Retirement Survey were asked to respond to hypothetical situations specifically designed to elicit information about their risk aversion, subjective rate of time preference, and willingness to substitute intertemporally. These three parameters are essential to individual choices about wealth accumulation, retirement, portfolio allocation, and insurance, as well as to policy choices that are dependent on this behavior.

Despite the analytic importance of these preference parameters, econometric studies have not fully resolved issues involving even their mean values. Indeed, even when the underlying parameter is constant across individuals, econometric estimation often relies on problematic identifying restrictions. The econometrician typically needs to posit a functional form. Instrumental variables are needed to control for potential endogeneities. The survey approach addresses these issues by constructing a survey instrument that is designed precisely to elicit the parameter of interest and that asks the respondent to control for differences in economic circumstances that confound estimation. While the survey approach introduces different problems--for example, whether the respondents are giving accurate answers--it can provide a potentially important source of information about behavior in addition to econometric evidence.

Econometric estimation of preference parameters may be particularly inadequate when heterogeneity of preferences in the population is important. 
In this case it may be desireable to have an estimate of the parameters of interest for each individual in a cross-section, not just the average value of that parameter in the population. Given individual level data, one would be able to study the covariation between the estimated parameters and observed behavior with regard to saving, portfolio choice, labor supply, insurance purchases, etc. Absent enough data to estimate the econometric model for each individual (i.e. a long panel), the standard econometric approaches cannot assign values of the parameter to specific individuals. ${ }^{1}$

The underlying purpose of our experiment is to explore the possibility of obtaining information about theoretically important parameters from direct questions involving choice in hypothetical situations, with as little departure from the theorist's concept of the parameter as possible. We obtain our measure of risk aversion by asking respondents about their willingness to gamble on lifetime income. By contrast, in the existing literature, most experiments involve small stakes, and even those involving large stakes put at risk at most a small fraction of an agent's assets once human capital is included among those assets.

Measures of intertemporal substitution and time preference are elicited by asking respondents to choose consumption profiles implicitly associated with different rates of return. According to the relevant economic theory, the two parameters are the solution of two equations in two unknowns. The questions typically asked about time preference in the literature do not properly distinguish between the subjective discount rate and the market rate of interest. As we emphasize in section $I I$, the rate at which individuals are willing to tradeoff present and future consumption depends on both. By asking

\footnotetext{
${ }^{1}$ Brown (1980) emphasizes the role of panel data in controlling for heterogeneity.
} 
for the preferred consumption path at more than one interest rate, we are able in principle to separate time preference from the market interest rate.

The organization of the paper is as follows. In section II we spell out our methods for measuring risk preference, intertemporal substitution, and time preference. In Section III, we report and discuss our empirical results. We also discuss the implications of our findings about risk preference for the equity premium puzzle. Section IV discusses related literature and Section $V$ contains a summary and conclusions.

\section{Methodology}

\section{A. Measuring Risk Aversion}

The principal feature of the question aimed at measuring risk aversion is that it must involve gambles on lifetime income. After considerable testing, ${ }^{2}$ in which the precise nature of the hypothetical circumstances were refined several times to minimize misunderstandings and additional complications envisioned by respondents, we arrived at the following question. ${ }^{3,4}$

Suppose that you are the only income earner in the family, and you have a good job guaranteed to give you your current (family)

\footnotetext{
${ }^{2}$ We tested preliminary versions of the survey instruments on two groups. Versions of the questions were first given to undergraduate economics students. Based on the student responses, we refined the questions. They were then tested as part of the standard Survey Research Center procedure for testing survey instruments. This phase of testing is meant to uncover difficulties respondents might have in interpreting the questions.

${ }^{3}$ See question $\mathrm{L} 14$ of the Health and Retirement Survey, Wave I (page 162 of the survey instrument).

${ }^{4}$ The questions ask about income rather than spending or consumption. After pre-testing, we concluded that survey respondents would better understand income than consumption lotteries. Given the low levels of financial wealth of most respondents, permanent labor income and permanent income are not that different. We investigate (see below) the extent to which high-wealth and older individuals respond differently to the questions.
} 
income every year for 1ife. You are given the opportunity to take a new and equally good job, with a 50-50 chance it will double your (family) income and a 50-50 chance that it will cut your (family) income by a third. Would you take the new job?

If the answer to the first question is "yes," the interviewer continues:

Suppose the chances were 50-50 that it would double your (family) income, and 50-50 that it would cut it in half. Would you still take the new job?

If the answer to the first question is "no," the interviewer continues:

Suppose the chances were 50-50 that it would double your (family) income and 50-50 that it would cut it by 20 percent. Would you then take the new job?

The questions separate the respondents into four distinct risk preference categories, depending on the answers to two questions. The categories can be ranked by risk aversion without having to assume a particular functional form for the utility function. Additionally, the responses provide bounds for the coefficient of relative risk aversion if one assumes that relative risk aversion is constant over the relevant range. The first question (whether the respondent would accept or reject a 50-50 gamble of doubling income or reducing it by $1 / 3$ ) separates respondents into those who have relative risk aversion less than 2 (who should accept) and those who have a risk aversion greater than 2 (who should reject). The next gamble (double or half) separates those who accept the first gamble into a group with risk aversion less than 1 (who should also accept this gamble) and one with risk aversion greater than 1 (who should reject). The last gamble (double or down 20 percent) serves to separate those who reject the first gamble into a class with risk aversion less than 3.76 (whose members should accept) and a class with risk aversion greater than 3.76 (whose members reject). 
We can analyze the results by grouping the respondents according to the four possible ranges of risk preference implied by their response to the questions. The first two columns of Table 1 show the upper and lower bounds of relative risk aversion consistent with each response to the survey. For most of the analysis, we work with the reciprocal of relative risk aversion, called "relative risk tolerance" in the finance literature. Risk tolerance aggregates linearly (see below, Section III). The next two columns of Table 1 give the ranges of relative risk tolerance consistent with the responses. It is also convenient to summarize the risk preference for each category with a single number. Based on an estimate of the underlying continuous distribution of relative risk tolerance, we can calculate the mean value of the parameter between the lower and upper bounds. ${ }^{5}$ The last column of Table 1 gives this mean relative risk tolerance for each range.

\section{B. Measuring Time Preference and the Elasticity of Intertemporal}

\section{Substitution}

Our experimental survey also sought to develop estimates of the desired slope of the path of consumption over time and the willingness of individuals to alter the slope of the consumption path in response to changes in the interest rate. These choices relate to two preference parameters: the rate of time preference and the elasticity of intertemporal substitution. To estimate these parameters, we attached an experimental set of questions to Wave I of the Health and Retirement Survey (designated Module K). In contrast to the questions about gambles over lifetime income, which are part of the

${ }^{5}$ This procedure is particularly useful in assigning a numerical value to the unbounded range of preference parameters associated with response IV. See Section II for a discussion of how we determine the underlying distribution of the parameter. 
main Health and Retirement Survey questionnaire, the questions in the experimental modules were asked only of a small subset of respondents.

In the experimental module, we first posed a hypothetical set of circumstances to the household that are meant to control for heterogeneity in economic and demographic conditions facing the household. Then the respondents were shown charts with different profiles of consumption with constant present value at a zero interest rate and were asked to chose the preferred path. In subsequent questions, they were asked to chose among constant present-discounted-value paths of consumption with interest rates of 4.6 and -4.6 percent per year. ${ }^{6}$ From the slopes of the preferred paths and how they change when the interest rate changes, we can estimate the rate of time preference and the elasticity of intertemporal substitution.?

The basic behavioral equation underlying our survey design for capturing time preference and intertemporal substitution is

$$
\Delta \log (c)=s(r-p)
$$

where $c$ is consumption, $r$ is the real interest rate, $\rho$ is the subjective discount rate, and $s$ is the elasticity of intertemporal substitution. This equation can be derived by assuming that the individual maximizes the present

${ }^{6}$ The present value of the consumption paths is the same within each set of choices (that is, for a given chart). The present value is not the same across charts (that is, for the different rates). In order to offer slope profiles that looked similar across charts, we had to vary the present value when we changed the interest rate. We also constructed the paths so that the level of consumption was a multiple of $\$ 500$ per month.

${ }^{7}$ The appendix presents the exact wording of the questions and shows the charts containing the consumption profiles from which the individuals chose. The survey instrument was subjected to the same type of testing as were the questions concerning risk aversion. 
discounted value of utility where the time-separable, period-by-period utility function has the form

$$
\mathrm{U}(\mathrm{C})=\frac{1}{1-\frac{\mathrm{I}}{\mathrm{s}}} \mathrm{C}^{1-\frac{1}{\mathrm{~s}}}
$$

Equation (1) says that if the real interest rate is high relative to the subjective rate of time preference, consumption will be growing over time. ${ }^{8}$ Agents start out with relatively low consumption in order to save and take advantage of the high rate of return. This effect will be larger the larger is $s$, which measures the strength of the willingness to intertemporally substitute in consumption. Given $r$ and $s$, the larger is $\rho$, the less upward-sloping will be the chosen consumption path, as households discount the future more heavily. If $\mathrm{r}<\rho$, the interest rate is not high enough to overcome the subjective discounting of the future, and agents choose consumption paths that (in expectation) fall as they age. This is nominally the same Euler equation routinely estimated on time series data by macroeconomists [see Hansen and Singleton (1983), Mankiw (1981), Mankiw, Rotemberg, and Summers (1985), and Hall (1988)].

Equation (1) contains two pieces of data, the percentage growth in consumption and the real interest rate, and two unknown parameters, $s$ and $\rho$. The two unknown parameters are not identifiable from just one observation on the rate of interest and the corresponding rate of consumption growth chosen

${ }^{8}$ Strictly speaking, equation (1) depends on the parameterization of the utility function (2) only if the $s$ in (1) is understood to be constant. Interpretation of our survey instruments does not require that $s$ be constant, although that parameterization of the utility function helps us to derive convenient summary statistics. 
by the agent. If the respondent is offered choices of consumption paths corresponding to two different interest rates, however, the two combinations of hypothetical interest rates and chosen consumption paths uniquely determine $s$ and $\rho$.

Our survey presents respondents with alternative consumption paths with the same present discounted value but different slopes. In the first question, the interest rate is zero. In subsequent questions, we offer different paths with the same present discounted value but either a higher or lower interest rate. We do not tell respondents that the present discounted values are equal across paths or how the interest rate is varying across questions. They simply choose the consumption path that most appeals to them in each of the situations they are faced with. ${ }^{9}$

To keep the questions simple, the respondent is asked to think of himself or herself as 50 years old, destined to live to the age of 80 . The years from 50 to 80 are then divided into two 15 year periods, "before retirement" from 50-65 and "after retirement" from 65-80. It offers a choice of levels of monthly consumption in the two periods. These levels of consumption are meant to be riskless. In particular, the respondents are told that health expenses are fully insured and that consumption is indexed for inflation. The respondent is offered the choice between five different combinations of pre-retirement and post-retirement spending, illustrated by bar graphs. At a zero real interest rate, he or she has the choice of spending $\$ 4000$ per month before retirement and $\$ 2000$ per month after

\footnotetext{
${ }^{9}$ The recent survey of TIAA-CREF participants asked qualitative questions as to whether households preferred flat, rising, or falling consumption paths. The present research is in that spirit, but involves an attempt at quantitative characterization of each household's intertemporal preferences. The TIAA-CREF data show a preference for rising consumption profiles, as do our results.
} 
retirement; or $\$ 3000$ per month both before and after; or $\$ 2000$ per month before and $\$ 4000$ per month after; or one of two other choices interpolated between these.

To determine $\rho$ and $s$, the respondent needs to be asked to choose between equal-present-value consumption paths for a second real interest rate. In order to be able to give the respondents even numbers to choose from, we chose the interest rate that would exactly double the real value of one's saving in the fifteen years between each year in the age-span 50-65 and the corresponding year in the age-span 65-80. This turns out to be a real interest rate of $\log (2)$ divided by 15 years (approximately 4.6 percent per year). As with the choices under the zero interest rate, these choices hold consumption constant within the 50-65 and 65-80 age spans. The choices for real monthly spending before and after retirement at this higher interest rate are $\$ 4000$ before, $\$ 1000$ after; $\$ 3500$ before, $\$ 2000$ after; $\$ 3000$ before and after; $\$ 2500$ before, $\$ 4000$ after; and $\$ 2000$ before, $\$ 5000$ after. Note that in this set of choices, each $\$ 500$ per month of pre-retirement spending that is sacrificed enables the individual to engage in $\$ 1000$ per month more postretirement spending.

Consider an individual who chose constant $\$ 3,000$ per month spending at the zero interest rate (the third column). Suppose the individual chooses the fourth column when confronted with the choices reflecting the positive interest rate: $\$ 2500$ per month spending from age 50 to age $65, \$ 4000$ per month spending from age 65 to age 80 . Since the difference between each point in the pre-retirement period and the corresponding point in the post-retirement period is 15 years, the implied slope of the consumption path between corresponding points is $\log (4000 / 2500) /(15$ years $)-3.1$ percent per year. This slope allows an easy calculation of the elasticity of intertemporal 
substitution: $s=(3.1-0) /(4.6-0)-0.67$. The subjective rate of time preference is then easy to calculate from (1). In this case it is zero. ${ }^{10,11}$

Although it is not necessary to try more than two interest rates, we used three, both as a check for consistency and to see how individuals responded to negative interest rates. There was a tendency for some respondents to react perversely when moving to a negative real rate, implying a negative elasticity of intertemporal substitution, although seldom one very different from zero.

\section{The Survey Instrument}

The questions were included in Wave I of the Health and Retirement Survey, administered to a large cross-section of households. The full survey, which takes about 2 hours to conduct, was conducted face-to-face in the field. It asks a wide range of questions concerning health status, retirement decisions, income, and assets. It also asks a number of behavioral questions, such as whether the individual smokes or drinks. In the case of couples, questions that pertain to individuals--including our questions on risk preference and intertemporal consumption preferences--are asked of both. Questions pertaining to the household as a whole, e.g. about wealth, are asked

${ }^{10}$ The indicator of time preference that we actually report in the empirical section of the paper is desired consumption growth at $r=0$, which is equal to $-s \rho$.

${ }^{11}$ These calculations presume that, for the given interest rates of zero and 4.6 percent, the selected paths are the ones that the respondent would most prefer. Since the survey instrument provides only 5 choices for the consumption path, it is likely that the most preferred path lies between two of the choices. Just as with the risk tolerance question, the responses to these questions are consistent with a range of preference parameters. When we present the results, we base the results on the range of parameters consistent with the responses (see below). 
of only a primary respondent. The primary respondent is the member of the couple "most knowledgeable" about the family's assets, debts, and retirement planning. ${ }^{12}$

The survey yielded 11,707 responses to the risk preference questions, 7,278 from primary respondents and 4,429 from secondary respondents. The experimental intertemporal consumption preference questions were given only to a very small subsample, yielding only 198 observations.

The risk preference questions were also included in one of the modules of Wave II of the Health and Retirement Survey. This module was asked of roughly ten percent of the sample, most of whom responded to the questions on Wave I. We use the multiple responses to the question to estimate the measurement error associated with the responses.

\section{Empirical Results}

We find substantial heterogeneity and interesting variation in the estimates of risk preference.

- The response exhibiting least risk tolerance was strongly modal. Hence, low risk tolerance characterizes most of the population.

- Nonetheless, there is substantial heterogeneity in risk tolerance. A significant fraction of the sample exhibited willingness to undertake substantial gambles over lifetime income.

\footnotetext{
${ }^{12}$ The first person contacted is asked to identify the most knowledgeable member of the family. There is a slight propensity for the first person contacted to over-report himself or herself as the most knowledgeable. For this point, and for a general analysis of this feature of the HRS, see Hill (1993). Members of couples need not be married. In our sample, 33 percent of the secondary respondents are males.
} 
- The measured risk tolerance has predictive power for choices over risky behaviors--the decisions to smoke and drink, to buy insurance, to immigrate, to be self-employed, and to hold stock. The behaviors studied are, nevertheless, very noisy and difficult to explain; the incremental predictive power of risk tolerance is never very high.

In this section, we present tabulations, cross-tabulations, and regressions that establish these findings.

\section{A. Distribution of True and Measured Risk Tolerance}

The survey groups the respondents into the four risk tolerance categories detailed in Table 1 . The survey response is, however, likely to be subject to noise. In this subsection, we describe a procedure for estimating the distribution of the true parameter and the distribution of the noise. This procedure is possible because a subset of respondents answered the risk tolerance questions in both Wave I and Wave II of the Health and Retirement Survey. ${ }^{13}$ By studying how the responses correlate across waves, we can quantify the signal and noise in the survey responses.

Consider the following model of relative risk tolerance, denoted $\theta_{j}$. Let

$$
x_{j}=\log \left(\theta_{j}\right)
$$

be the logarithm of individual $j$ 's true relative risk tolerance and let $\epsilon_{j k}$ be an independent error associated with the individual's response to the survey $k$

${ }^{13}$ We do not use other information from Wave II. Wave II is currently in beta release. Many variables have not yet been recoded and imputed. 
( $k$ - Wave I or Wave II). The true parameter is assumed to remain constant, but the error $\epsilon_{j k}$ may differ across administrations of the survey. The realized $\log$ risk tolerance

$$
y_{j k}=x_{j}+\epsilon_{j k}
$$

equals the true $\log$ risk tolerance plus a noise. Let $B_{1}$ be the ranges of risk tolerance given in Table 1 for each category $i$ - I, II, III, and IV. We assume that an individual will choose response $i$ if $y_{j k} \in B_{i}$. That is, there is noise in how an individual will report his or her risk tolerance on a given day, but given the noise, the individual calculates correctly which gamble to accept. ${ }^{14}$ Note that this model is quite different from the standard latent variable model. In the standard model, the latent variable $x_{j}$ and the cutoffs defining $B_{i}$ are based on an arbitrary index. In contrast, our latent variable is a cardinal preference parameter and the cutoffs are known numbers.

With one response per individual, we would have been able to estimate only the distribution of $y_{j k}$, not the distribution of the true parameter $x_{j}$. But 717 individuals responded to the risk preference questions on both waves. This allows us to estimate the distribution of the true parameter and to quantify the noise. To implement this statistical model, we assume that $\theta_{j}$ is distributed lognormally across individuals. ${ }^{15,16}$ The maximum likelihood

${ }^{14} \mathrm{An}$ alternative would be that there is no noise in the preference parameter, but the individual uses noisy cutoffs. The former interpretation implies some noise in preferences. The latter places the noise in interpreting the questions. These two interpretations yield the same statistical mode1.

${ }^{15}$ The lognormal specification takes into account that $\theta$ is non-negative and that the observations bunch at the lower risk tolerances (see below, Table $3)$. 
estimate of the mean of $\log$ risk tolerance $x_{j}$ is -1.96 . The estimated standard deviation of $\mathrm{x}$ is 1.03 and of $\epsilon$ is $1.39 .{ }^{17}$ These parameter estimates yield a mean true risk tolerance $\theta$ of 0.24 . The estimated correlation of 0.60 between the true ( $x$ ) and reported (y) log risk tolerance is quite high.

Table 2 uses these estimates to show the expected value of relative risk tolerance $\theta_{j}$ conditional on an individual responding I, II, III, or IV to the risk preference questions in Wave $I{ }^{18}$ Were there no measurement error, the expectations in Table 1 and Table 2 would be equal. Because of the measurement error, the expected value of the preference parameter given the survey response reverts toward the unconditional mean. We use the expected values in Table 2 to assign numerical values of the preference parameter to individuals according to their response to Wave I. Table 2 also shows the expected value of relative risk aversion conditional on an individual responding I, II, III, or IV. Note that expected risk aversion is substantially greater than the reciprocal of expected risk tolerance. Jensen's inequality is strong. We discuss the economic significance of Jensen's inequality in Section III-D.

If one is interested only in predicting behavior based on the response to the risk preference questions, these numerical assignments can be ignored.

\footnotetext{
${ }^{16}$ The estimation uses all the observations, including those who answer only one of the two waves. The likelihood is constructed from the trivariate normal distribution of $x_{j}, y_{j 1}$, and $y_{j 2}$ and the bivariate normal distribution of $x_{j}$ and $y_{j k}$ for those who answered only $k=$ Wave $I$ or Wave II. Hence, those who answer only one wave help us estimate the distribution of $y$, while those who answer both allow us to identify the distributions of $x$ and $\epsilon$. The distributions are integrated over the truncation intervals $B$ for $y$ to yield the likelihood.
}

${ }^{17}$ Standard errors of the estimated parameters are approximately 0.01 .

${ }^{18}$ This expectation is computed by integrating $e^{x}$ over the joint probability distribution of $x$ and $y$. 
That is, behavior can be related to the categorical responses I, II, III, and IV. We present such results in cross-tabulations. These cross-tabulations also have the advantage of not relying on our particular model of response noise or on the distributional assumptions required to estimate it. We also present regressions relating the parameters to behaviors. These could also be based on dummies for each response, but the numerical assignments have the advantage of imposing the restriction that responses I through IV are increasingly risk tolerant. Moreover, to give the predictions a structural interpretation, the measurement error must be taken into account.

\section{B. Heterogeneity in Individuals' Risk Tolerance}

Table 3-A gives the fraction of all respondents that fall into risk tolerance groups I, II, III, and IV and the mean risk tolerance using the expected values for each category given in Table $2 .{ }^{19}$ The mean risk tolerance is 0.24 . Heterogeneity is also substantial. Most respondents are in category $I$, but a significant minority are in the higher risk tolerance categories. Based on the estimated underlying lognormal density, the standard deviation of risk tolerance is $0.33 .{ }^{20}$

Tables 3-B through 3-Y present cross-tabulations. The last column gives the marginal significance level (the "p-value") for the test of the hypothesis that the mean risk tolerance is equal across the rows of the tables. ${ }^{21}$

${ }^{19}$ When an individual responded to both wave $I$ and Wave II, we condition on both responses to assign the expected risk tolerance. follows:

${ }^{20}$ The fractiles of the distribution of relative risk tolerance $(\theta)$ are as

$\begin{array}{cccccccc}\text { Fractile } & 0.05 & 0.10 & 0.25 & 0.50 & 0.75 & 0.90 & 0.95 \\ \theta & 0.03 & 0.04 & 0.07 & 0.14 & 0.28 & 0.53 & 0.77\end{array}$

${ }^{21}$ The number of observations $(N)$ in the different tabulations vary slightly owing to missing data. 
Table 3-B give the results separately for the primary and secondary respondents. The distribution of responses across the four risk tolerance categories and mean risk tolerance are nearly identical for the two groups.

The rows of Table $3-C$ show the distribution of responses of the secondary respondent conditional on the response of the primary respondent. The correlation is substantially positive--the diagonal elements are substantially larger than the unconditional distribution shown in Table 3-B. The correlation of the numerical measure of risk tolerance across household member is only 0.12 , but is strongly significant (t-statistic of 7.8 ). ${ }^{22}$

The results in the previous subsection documented that there is substantial heterogeneity in risk preferences across individuals. In this subsection, we ask whether the differences in risk tolerance vary with characteristics that are exogenous with respect to the individual.

Table 3-D shows that there are substantial differences by age in estimated risk tolerance. ${ }^{23}$ The youngest and the oldest cohorts are the most risk tolerant, with cohorts in the middle being less risk tolerant. The groups under 55 years old choose the least risk tolerant choice (I) relatively infrequently; the group over 70 chooses the most risk tolerant option (IV) relatively frequently. Ages 55 to 70 are relatively risk intolerant. We can reject with a high degree of confidence (p-value of 0.0001 ) that the mean risk tolerance of these age groups is equal.

There are also differences in risk tolerance by sex. Table 3-E shows that males are somewhat more risk tolerant than females, with the biggest

${ }^{22}$ We have no strong prior belief about the degree of correlation of the preference parameters of married individuals. It is not clear that risk tolerance would be a key variable upon which there is assortative mating.

${ }^{23}$ Since the data is a cross-sectional survey done at a point in time, age and year of birth are the same effect. Hence, we cannot distinguish between the pure effects of aging and common preferences shared by a birth cohort. 
difference being in males' propensity to choose the most risk tolerant option (IV). Again, the differences are statistically significant.

There are dramatic differences in risk tolerance by the race and religion of the respondent. Table $3-\mathrm{F}$ gives the results by race and Table $3-G$ gives those by religion. Whites are the least risk tolerant, blacks and native Americans somewhat more risk tolerant, and Asians and Hispanics the most risk tolerant. Again, the differences are easiest to see in the columns I and IV giving the extreme responses. For example, Asians are 7 percentage points less likely than whites to choose the least risk tolerant response and are 9 percentage points more likely to choose the most risk-tolerant response. Risk tolerance also varies significantly by religion. Protestants are the least risk tolerant and Jews the most. In risk tolerance, Catholics are about halfway between Protestants and Jews.

\section{Is Risk Tolerance Related to Behavior?}

Someone skeptical of preference measures based on responses to hypothetical situations might well maintain the null hypothesis that the measures are unrelated to actual behavior. In this subsection, we examine the extent to which measured risk tolerance predicts risky behavior. By showing that our measure of risk tolerance predicts behavior in the way one would expect, we can partially "validate" the survey measure. The risk tolerance measure indeed predicts risky behaviors--including smoking, drinking, having insurance, choosing risky employment, and holding risky assets. These results are often strongly significant statistically and are associated with quantitatively significant coefficient estimates. We can decisively reject the null that the measured preference parameters are unrelated to behavior. 
We therefore treat the relationship of measured risk tolerance with various behaviors as something of interest in its own right. We stop far short of constructing a complete theory of all the behaviors that are potentially related to risk preference. Rather, we present cross-tabulations analogous to the ones in the previous subsection. We also estimate some simple, linear regressions in an attempt to control for some correlates of risk preference. This approach does allow us to an extent to evaluate whether the significant patterns relating risk preference to the various tabulated behaviors are merely relabelling a single, underlying factor.

Smoking and Drinking. Tables 3-H, 3-I, and 3-J tabulate risk tolerance by smoking and drinking--behaviors that increase health risk. The corresponding regression estimates are reported in columns (i)-(iv) of Table 4. Individuals who have ever smoked are more risk tolerant than those who never smoked and those who smoke now are more risk tolerant than those who do not smoke now. Of particular interest are those who say they once smoked, but do not smoke now. The sample is largely composed of middle-aged to older individuals. Hence, those who quit smoking would have done so during a period of increasing public awareness of the risks associated with cigarette smoking. Those who quit smoking are somewhat more risk tolerant than those who never smoked, but less risk tolerant than current smokers.

Whether an individual drinks or not is also related to measured risk tolerance. Risk tolerance is higher for those who drink than those who do not drink (Table 3-I). The difference in risk tolerance between drinkers and nondrinkers is about the same as between smokers and non-smokers. Moderate drinking is not generally believed to be a health risk. Table 3-J tabulates risk tolerance by drinks per day. Those who take less than one drink per day have a willingness to accept the moderate gambles (II and III) relatively 
often. As drinks per day increase, there is a monotonic increase in mean risk tolerance. For heavy drinkers, risk tolerance--measured either by willingness to choose gamble IV or by mean risk tolerance--is substantially above average. Therefore, our measure of risk tolerance does predict whether the individual undertakes behaviors that pose health risks.

The risk tolerance measure predicts smoking behavior even after controlling for the demographic variables. Column (i) of Table 4 shows that risk tolerance remains statistically significant in the equation for "ever smoked" and "smoke now." The results in show that the most risk tolerant respondents are over $3-1 / 2$ percentage points more likely to have ever smoked than the least risk tolerant respondents $(0.0922$ times the 0.42 difference between the expected risk tolerances of a respondent in categories I and IV). Therefore, risk tolerance provides a substantial amount of information compared to other factors. For example, a Catholic respondent is about 5 percentage points more likely to have ever smoked, other things equal. In general, the loading of risk tolerance is of the same magnitude as the loading of the demographic factors.

Thus, our measure of risk tolerance is a strongly significant predictor of smoking behavior and is about as helpful in predicting smoking behavior as any of the demographic variables. That said, it is important to note how little of the variance of smoking behavior is explained by risk tolerance. The measure of risk tolerance explains less than 0.1 percent of the variance of smoking behavior.

Risk tolerance is also a significant explanatory variable for drinking behavior even after controlling for demographic variables. Table 4-iii shows that moving from the lowest to highest response for risk tolerance is associated with a 4 percent increase in the probability of drinking ( $t$ - 
statistic of 3 ) and a 0.1 drink increase in the number of drinks per day ( $t-$ statistic of 4-1/2). As with smoking, the incremental explanatory power of the risk tolerance measure is low; again there is substantial unexplained variability in drinking behavior..$^{24}$

Education and Employment Status. Table $3-\mathrm{K}$ shows that there is a $\mathrm{U}$ shaped relationship between years of schooling completed and our measure of risk tolerance. Individuals with exactly 12 years of schooling are the least risk tolerant. Indeed, the mean risk tolerance of 0.229 and average propensity to choose response IV of 10.2 percent are the lowest we found for any group that we categorized. Those with less than 12 or 13 to 16 years of schooling have slightly greater than average risk tolerance. Those with some post-college education (years greater than 16 ) have substantially greater than average risk tolerance. In the multivariate analysis (Table 4-v) the number of years of schooling is not associated with risk tolerance--in part because of the nonlinearity we found in the cross-tabulation. The sign of the coefficient is positive, but it is very small and is not significantly different from zero.

Among the biggest risks voluntarily taken by a large segment of the population is self-employment. The self-employed generally face a riskier overall income stream than their wage-earning or salaried counterparts [see Friedman (1957), Carroll (1994)]. Thus, one would certainly expect risk

\footnotetext{
${ }^{24}$ Researchers have studied attitudes about health-related risk and examined how these interact with economic choices. The relationship between our risk tolerance measure and smoking and drinking corroborates the findings that individuals translate health risks into pecuniary values. Viscusi and Evans (1990) estimate that workers show rather smooth, concave tradeoffs between occupational health and safety risks and consumption. Fuchs (1982) shows that the substantial heterogeneity in responses to questions about money or commodities now versus the corresponding desiderata in the future has predictive power for the decision to smoke, and that some, but not all of this is mediated through education.
} 
tolerance to be positively associated with the decision to undertake self-employment. Table 3 -L shows that the self-employed are more risk tolerant than employees. ${ }^{25}$ The multivariate analysis shows that the most risk tolerant respondents are about one percentage point more likely to select self-employment than the least risk tolerant respondents (Table 4-vi). Given that the probability of self-employment is less than 12 percent, this is a quantitatively large effect, but it is not statistically significant ( $t$ statistic of 1.1).

Health and life Insurance. Anyone with positive risk aversion should be fully insured against purely financial risks when insurance is actuarially fair. In the presence of a load factor, however, those who are most risk averse should be most willing to buy insurance against financial risks. A complication arises (as with smoking and drinking) because the kinds of insurance purchases on which we have information are health and life insurance, where the risks are not purely financial--the marginal utility of wealth potentially depending on health status, for instance. Again, we appeal to financial responsibility for the support of others as the basis of our a priori expectation that the (financially) more risk averse are more likely to purchase both medical and 1 ife insurance. ${ }^{26}$

\footnotetext{
${ }^{25}$ There is no obvious prediction about the risk tolerance of those not working--mainly retired individuals and spouses not in the labor force.

${ }^{26}$ Researchers have used choices about insurance to elicit estimates of risk aversion. Friedman (1973) used data on choices regarding health insurance, and obtained an estimate of about 10. Szpiro (1986) returns to the idea of gauging risk aversion by studying the demand for insurance. He looks at households' willingness to pay a load factor in order to obtain insurance, using insurance company data on premiums and claims. Using these data, along with the Goldsmith data on total household wealth, Szpiro reports estimates of the coefficient of relative risk aversion between one and two. While these studies are clearly related to our results, their method is to estimate risk aversion from purchase of insurance while our survey creates an independent measure of risk aversion, which can then be related to purchase of insurance.
} 
Table 3-M examines our measure of risk tolerance according to whether or not the individual has health insurance. We do separate tabulations for employees, the self-employed, and those not working. To focus on those who might have the option of having insurance or not, this tabulation excludes those in the Medicare-eligible age group.

For each of the three employment classes, more risk tolerant individuals are less likely to have health insurance. For those employed, risk tolerance as measured by our experimental measure seems to be an important factor sorting individuals into jobs with health insurance. For the not employed, risk preference is a powerful discriminator of the propensity to be insured. ${ }^{27}$

Having life insurance is predicted in the way one would expect by risk tolerance (Table $3-\mathrm{N}$ ).

The results in the cross-tabulations for health and life insurance carry over when the demographic factors are controlled for. The high-risk tolerance respondents are 8.2 percentage points more likely to not have health insurance and over 6-1/2 percentage points more likely to forgo life insurance than the least risk-tolerant respondents. Both results are highly statistically significant ( $t$-statistics in excess of 5 ) and are quantitatively important. (See Table 4, columns vii and viii).

Region and Immigrant Status. An epic risk is to move to a new country in search of a better life. The idea that immigrants are more daring than the average person is part of the American mythology. Migration within the United States could also entail significant risks. The western United States has in

${ }^{27}$ The effect of risk tolerance on the propensity to be insured is smaller among the self-employed than among the unemployed. Between groups, the selfemployed have a higher risk tolerance and have much lower average propensity to be insured than employees. 
the past been an internal frontier to which one might argue the more daring have migrated. Some of the attitudes from that frontier past may have persisted to the present.

Both region of residence and immigrant status are significantly predicted by risk tolerance. Residents of the western United States are more risk tolerant than residents of other regions (Table 3-0). Immigrants are also substantially more risk tolerant than natives (Table 3-P). Indeed, immigrants have one of the highest probabilities of being in category IV of any group that we isolate.

Given that many recent immigrants are Hispanic and Asian and that Hispanics and Asians have high risk tolerance (see Table 3-F), it is important to check that immigrant status is not confounded with ethnicity. The positive association of risk tolerance and immigrant status survives controlling for the demographic factors, but has a t-statistic of only $1-3 / 4$.

Income and wealth. Tables $3-Q$ and 3-R tabulate risk tolerance by quintiles of income and wealth. Risk tolerance decreases with income and wealth until the middle of the distributions, and then increases. Note that the pattern of risk tolerance by income and wealth is similar to that for age. Risk tolerance rises at the high end of the wealth, income, and age distributions . ${ }^{28}$

\footnotetext{
${ }^{28} 01$ der and high wealth individuals might interpret the survey questions differently from most respondents because labor income is a smaller fraction of their current resources. We checked for this possibility by grouping the responses by both age and wealth quintile. These groupings do not lead to the conclusion that the highly risk tolerant respondents are either old or wealthy. Moreover, we reran the regressions in Table 4 including the logarithms of income and wealth as regressors. Controlling for income and wealth raises some coefficients of risk tolerance and lowers others, but overall has little qualitative impact on the findings. (We report the regressions without wealth and income in Table 4, owing to concern about the endogeneity of those variables.)
} 
Assets. Tables 3-S through 3-Y relate choice of assets to risk tolerance. The questions about assets apply to the household. In the Health and Retirement Survey, they are answered by the "knowledgeable respondent"-the member of the household with the best knowledge of the household's assets. The assets are characteristics of the household (there is no information on asset ownership within the household), while risk preference is a feature of individuals. In the tabulations, we treat members of two-person households as individual observations. By separately attributing the total assets of the household to each member, we effectively average their risk tolerances. We take into account different risk tolerances within households in the regressions reported in Table 4 (see below).

Table 3-S tabulates risk tolerance according to whether or not the household owns its home. The 20 percent of individuals who do not live in houses they own are substantially more risk tolerant than those who own their homes. Homeownership remains negatively associated with risk tolerance after controlling for the demographic variables. It is not obvious what correlation one would expect a priori. Although house prices are volatile and houses are often highly leveraged, owning a house insulates individuals from local changes in the cost of shelter, and thus provides some consumption insurance. Additionally, those who do not own homes might be especially interested in gambles that might make homeownership possible.

For choice among risky assets that are held strictly as investments, the predictions about the relationship between risk tolerance and holding risky assets is more straightforward. We would expect risky assets to be held in greater proportion by those with higher risk tolerance. In Table 5, we 
examine portfolio shares. As a first look at the asset data, in this section we condition simply on whether or not the individual owns any of the asset. ${ }^{29}$ Ownership of a business (Table $3-T$ ) is predicted by risk tolerance in the way one would expect, but only very weakly so. Similarly, stock and bond ownership are positively, but weakly correlated with risk tolerance (Tables $3-U$ and $3-V$ ). On the other hand, having a checking or savings account, Treasury bills, or an IRA or Keogh account are all negatively correlated with risk tolerance (Tables $3-\mathrm{W}, 3-\mathrm{X}$, and $3-\mathrm{Y}$ ). ${ }^{30}$ While the negative relationship between holding Treasury bills and risk tolerance (Table $3-\mathrm{X}$ ) can reasonably be seen as the effect of risk preference on portfolio choice, the relatively high risk tolerance of those with no savings or checking account (Table $3-W$ ) probably says more about the conditions of those who have no accounts for transactions than about portfolio choice.

Table 5 presents regressions of portfolio shares on the demographic variables, risk tolerance, wealth, and income for a subsample that has positive financial assets. Many households have little or no financial wealth. We limit this analysis to households that have at least $\$ 1000$ in financial wealth. This criterion excludes about one-sixth of the households. Since asset ownership depends substantially on income and wealth, we include these as controls in the regressions of portfolio variables. Recall that the risk tolerance measure is positively, but not strongly, correlated within

${ }^{29}$ Given that Tobin's Separation Theorem says that all individuals should hold the same portfolio of risky assets, it is remarkable how many individuals own no stocks (over 70 percent of individuals) and no bonds (almost 95 percent of individuals).

${ }^{30}$ The Health and Retirement Survey fails to provide any information about the asset composition of retirement accounts. Given the growing importance of retirement accounts and defined contribution pension plans, it is important that future surveys provide information about the composition of these accounts. 
couples (Table $3-C$ ). To study the role of potentially conflicting risk tolerances within the family, we enter the risk tolerance of members of couples separately. Hence, the regressions include the risk tolerance of the primary respondent ( $R 1)$ and the difference between the risk tolerance of the primary and secondary respondent $(\mathrm{R} 1-\mathrm{R} 2) .^{31}$

The risk tolerance measure has significant predictive power for stock ownership. In households where the primary respondent gave the most risktolerant response, the fraction of financial assets held in equities is 4.1 percentage points higher on average than in those where the primary respondent gave the least-risk tolerant response. Since the average fraction of portfolios in stocks is only 14 percent, this effect is substantial. It is also strongly statistically significant. If the secondary respondent is less risk tolerant than the primary respondent, the stock share is lower, although this estimate is not statistically significant from zero.

Similarly, less risky assets--Treasury bills and savings accounts--make up relatively more of the portfolios of the relatively less risk tolerant respondents. Bonds are too small a share of portfolios for the results to be decisive ( 1.4 percent of portfolios on average), although there is a marginally significant positive relationship between bond holding and risk tolerance. Ownership of other assets (trusts, collections held for investment) is powerfully related to risk tolerance. Yet, the relationship between risk tolerance and the holding of risky assets is much weaker than theory suggests. In theory, the elasticity for the share of each risky asset should be 1. The estimated coefficients of risk tolerance in Table 5 can be

\footnotetext{
${ }^{31}$ If there is no secondary respondent, we code the difference as zero. If the secondary respondent did not answer the risk tolerance question, we also code the difference as zero. If the primary respondent did not answer, we exclude the household from the sample. The values of the other individualspecific covariates refer to the primary respondent.
} 
expressed as elasticities. The elasticity of the stock portfolio share with respect to risk tolerance is estimated to be 0.17 , of the bond share to be 0.25 , and of other assets to be 0.21 .

Therefore, for assets at opposite ends of the risk spectrum--stocks at one end versus Treasury bills and savings accounts at the other end--the risk tolerance measure has substantial explanatory power for portfolio demands.

D. Heterogenous Risk Preferences and the Equity Premium Puzzle

In this section, we discuss how to aggregate our estimates of individuals' risk tolerance in a way that informs the demand for stockholding. In particular, we ask whether the answer to the "equity premium puzzle" [Grossman and Shiller (1981) and Mehra and Prescott (1985)] might simply lie in the fact that most agents are very risk averse, as indicated by the high percentage of respondents in the least risk-tolerant category. We demonstrate here that our findings are in fact not consistent with this story. Although most individuals are risk averse, there are enough risk tolerant individuals to hold the outstanding supply of equity at far less than the historically observed risk premia. Equivalently, because finance theory implies that in aggregating preferences across individuals the least risk averse receive the greatest weight, the effective risk aversion of the representative consumer is actually rather low. These statements are robust to different ways of treating nonstockholders.

What is the appropriate way to use our estimate of the population distribution of preferences to aggregate the heterogeneous individuals and construct a single number for use in an asset demand equation? One might be tempted to take a simple (weighted or unweighted) arithmetic average of risk aversion over all individuals. But in the aggregation of a capital asset 
pricing model, those with greater willingness to bear risk ought to receive greater weight, since they tend to take large positions in risky assets. More specifically, individual asset demands--which can be aggregated by simple addition--involve a term that is proportional to risk tolerance [see Breeden (1979)]. Taking a simple average of risk tolerance yields the harmonic mean of risk aversion, which is always smaller than the arithmetic mean of risk aversion. In the first column of Table 6-A, we show average relative risk tolerance, computed using the numerical assignments, and with the theoretically mandated consumption weights proxied by equal weights, income weights, and wealth weights, respectively. In the second column, we show the weighted average of relative risk aversion. The difference between risk tolerance and the reciprocal of risk aversion is substantial: The reciprocal of the mean risk tolerance of 0.24 equals 4.2 while mean risk aversion is 12.1. The result is not very sensitive to the weighting. Hence, the heterogeneity we find implies a dispersion in risk preferences that is large enough to make the difference between the arithmetic mean and the harmonic mean an important one.

A large group of individuals do not hold stock at all. If these individuals hold zero net positions because of fixed costs of being in the stock market and/or constraints on short sales (rather than because their unconstrained optimum stockholding is precisely zero), they require special treatment. In Table 6-B, we repeat our previous calculations, assigning nonstockholders zero risk tolerance, since they show no effective willingness to bear stock market risk. In Table 6-C, we show risk tolerance for stockholders only. Table 6-C fairly closely replicates the numbers for all respondents without special treatment of nonstockholders. Although the precise risk tolerance estimates are two to three times larger for the whole 
sample (Table 6-A) than when non-stockholders are assigned zero risk tolerance (Table 6-B), the qualitative conclusions above continue to hold. The risk-averse majority is not important enough to explain the equity premium puzzle. ${ }^{32}$

E. Intertemporal Elasticity of Substitution and Time Preference in Consumption

In this section, we report the results of our experimental survey questions designed to elicit estimates of the preference parameters governing intertemporal substitution and time preference. We added the experimental "Module K" described in Section II and the Appendix to the first wave of the Health and Retirement Survey. As with the other experimental modules, Module $K$ was administered to a very small subset of the HRS respondents: There are 198 respondents. In contrast, there are more than 11,000 responses to the risk preference questions discussed in the previous sections. In 1 ight of the small sample, the results should be regarded as tentative. Nonetheless, we can characterize our results broadly as follows:

- Most individuals have low elasticities of intertemporal substitution. Our point estimate for the average elasticity of intertemporal substitution is 0.18 . Virtually no respondents have intertemporal substitution as elastic as that implied by $\log$ utility.

- Although the mean elasticity of intertemporal substitution is only slightly less than the mean risk tolerance, there is

\footnotetext{
${ }^{32}$ Mankiw and Zeldes (1991) find that the consumption of stockholders is more correlated with stock returns than non-stockholders, but that the correlation for stock holders is still very small. Thus, their finding parallels ours about risk aversion.
} 
essentially no relationship between individuals' estimated elasticity of intertemporal substitution and relative risk tolerance.

- The modal time preference is for slopes of consumption paths near zero, but the mean preference is for an upward sloping consumption path.

The remainder of this section presents these results in more detail and discusses some of the problems that arose in the experimental survey.

Unlike the risk preference questions, the questions about the slope of the consumption path had possible responses that are either uninformative about the elasticity of intertemporal substitution or are inconsistent with utility maximization. For example, respondents who--regardless of the interest rate--chose either the extreme positive slope (choice E) or the extreme negative slope (choice A) could have any elasticity of intertemporal substitution. Since they are at a corner (given the range of choices we present), we do not learn anything about their willingness to substitute intertemporally when confronted with different interest rates. of the 198 respondents to the experimental module, 24 (12 percent) gave such uninformative responses. Since they convey no information about intertemporal substitution, they are left out of those tabulations.

Moreover, unlike the questions about risk tolerance, the set of possible responses to the questions on the experimental module left open the possibility of responses that were inconsistent with utility maximization. While we leave these out of the tabulations, it is important to examine the nature and extent of these inconsistent answers. The first question ( $\mathrm{K} 1$ in the Appendix) offered three consumption profiles (A,C, and E). This was meant as a warm-up to familiarize the respondents with the form of the questions. 
The second question (K2) offered the same three choices plus two intermediate possibilities ( $B$ and $D$ ). Sixteen ( 8 percent) of the respondents made inconsistent choices (e.g. switched from $\mathrm{E}$ on $\mathrm{K} 1$ to $\mathrm{C}$ on $\mathrm{K} 2$ even though $\mathrm{C}$ was a choice in $\mathrm{K} 1$ ). We eliminated these respondents from the tabulation even if their subsequent responses were otherwise consistent. Another 42 respondents (21 percent) displayed other inconsistencies in the subsequent choices. Specifically, these involved changing the slope of the desired consumption path in the direction opposite the change in the interest rate. There was, in particular, some tendency for respondents to react perversely when moving to a negative real rate, implying a negative elasticity of intertemporal substitution, although not one very different from zero. We excluded these observations.

Results: Intertemporal Substitution. Excluding the responses that are either uninformative about intertemporal substitution or are inconsistent, we are left with 116 useful observations. Just as with the risk preference question, the discrete nature of the survey questions lead to responses that correspond to ranges of preference parameters. Because we present the respondents with a fairly rich set of consumption profiles, the responses cannot be categorized into a few, non-overlapping groups, as they were for the risk preference. The respondents are presented five slopes for each of the three interest rates (zero, positive, and negative). ${ }^{33}$

For each valid response, we calculate the range of possible elasticities of intertemporal substitution and most-desired slopes of the consumption path at a zero interest rate that are consistent with the responses. These

\footnotetext{
${ }^{33}$ Some respondents were given the opportunity to give a second choice in order to give tighter estimates of the preference parameters. We do not use this information because the second choice was added late and there are many missing second choices.
} 
calculations are analogous to the ranges for the risk preference parameters given in Table 1. Table 7 summarizes the preference parameters of the respondents. The first row gives the elasticity of intertemporal substitution. The second row gives the rate of time preference as measured by the slope of the desired consumption path at a zero interest rate. For each respondent's answers to the questions in the experimental module, we calculate the lower bound and the upper bound of both parameters. The averages across respondents of these lower and upper bounds are reported in the first two columns of Table 7. The third column reports the average of the midpoints between the minimum and maximum.

The average of the estimated lower bounds of the intertemporal elasticity of substitution is very close to zero. The average of the estimated upper bound is 0.36 . The average midpoint is 0.18 . The average lower bound is as low as it is because the responses for most households (103 of the 116 valid responses) are consistent with zero elasticity of intertemporal substitution. Indeed, the most common response was to choose a flat consumption profile (response $C$ ) as the first choice regardless of whether the interest rate was zero, positive, or negative. The next most common response was to choose the moderately upward sloping path (response D) for each interest rate. Eighty-four ( 72 percent) of the valid responses fell into these two groups. Because the interest rate is varying across the paths, these responses provide a fairly tight upper bound on the elasticity of intertemporal substitution. For those always preferring response $C$, the upper bound is 0.23 (not taking into account second choices). The upper bound is 0.29 for those always preferring $D$.

The remaining 28 percent of the valid responses did not fall into tight groupings. Many showed greater elasticity of intertemporal substitution--a 
midpoint as high as 1.08 for one respondent. Yet, even among those for whom intertemporal substitution is bounded away from zero, preferences are rarely as elastic as $\log$ utility. Only 2.5 percent of respondents had maximum elasticity of intertemporal substitution greater than or equal to one.

Figure 1 summarizes these results by showing the estimated density of the preference parameters. ${ }^{34}$ Most of the mass of the distribution of the elasticity of intertemporal substitution is between zero and 0.35 . Yet there is some mass between 0.35 and 0.65 . Very few individuals had elasticities greater than 0.65 . There is no evidence of an elasticity of intertemporal substitution anywhere near 1 , which has been assumed in calibration exercises. The wide grid size used for the five alternatives makes it difficult to measure accurately the difference between an elasticity of intertemporal substitution of, say .1 and .3 , but it is sufficiently narrow to preclude values closer to unity than to zero, a result consistent with Hall (1988). Results: Time Preference. Table 7 and Figure 1 also give results for the time preference parameter. The overall average slope of the desired consumption path is 0.78 percent per year. Figure 1 shows that most responses include zero slope, but a tendency to prefer a positive slope is somewhat more common than a tendency to prefer a negative slope. Thus, we confirm the findings by experimental and cognitive psychologists (see below) that there is some evidence for a negative time-discount rate--in other words, on average, people prefer an upward sloping consumption profile, even when the interest rate is zero.

\footnotetext{
${ }^{34}$ The density reflects both the range of possibilities for each respondent and the variation in these ranges across respondents. It is constructed by adding up rectangles whose height is the reciprocal of the range of the individuals' responses.
} 
Intertemporal Substitution versus Risk Tolerance. Many applications assume that a representative consumer maximizes a time- and state-separable utility function with the period-by-period function having the functional form given in equation (2). In this context, relative risk tolerance (the reciprocal of relative risk aversion) equals the elasticity of intertemporal substitution. Selden (1978) and Epstein and Zin (1989) have discussed preferences where the individual's elasticity of intertemporal substitution is not equal to risk tolerance. Weil (1990), Hall (1988), and Barsky (1989) explore the implications of such preferences for consumption and asset pricing while Kimball and Weil (1992) discuss the implications of these preferences for precautionary saving. ${ }^{35}$ For the respondents to our experimental survey, we can test directly whether there is a relationship between risk tolerance and intertemporal substitution.

Table 8 tabulates the consumption path parameters by the four responses to the risk preference question. There is no significant relationship--either statistically or economically--between risk tolerance and intertemporal substitution. ${ }^{36}$ Similarly, if we regress the estimated elasticity of intertemporal substitution (measured by the midpoint of the range of possible values for each respondent) on the mean risk tolerance, we get a coefficient of 0.01 with a standard error of 0.02 . Under the usual assumption that risk tolerance equals the reciprocal of the elasticity of intertemporal substitution, the regression coefficient should be one. Hence, it appears

\footnotetext{
${ }^{35}$ Certain utility functions that display habit formation or consumption externalities also can break the link between risk tolerance and intertemporal substitution. This is an important feature of Campbell and Cochrane's (1994) analysis. Andrew Abel's discussion of that paper at the October 1994 NBER Economic Fluctuations meeting clarified this point for us.

${ }^{36}$ The slope of the consumption path is noisier, but also shows no relationship with risk preference.
} 
that there is no relationship between measured intertemporal substitution and measured risk tolerance even though the means are similar.

Given the scant number of observations from the experimental Module $\mathrm{K}$, we do not consider tabulations with the demographic and behavioral variables.

\section{Related Literature}

\section{A. Risk Aversion}

Economists have applied a number of techniques to elicit estimates of agents' relative risk aversion. Friend and Blume (1975) study the demand for risky assets relative to safe assets. Their conclusion that the coefficient of relative risk aversion is undoubtedly greater than unity anticipates the "equity premium puzzle."37 Mehra and Prescott (1985), using consumptionbased models, find that the coefficient of relative risk aversion must be well in excess of 10, probably an order of magnitude larger, to match the large observed equity premium. A number of studies examine the relationship between the growth rate of consumption and real interest rates. These measure risk aversion only in the special case where risk aversion coincides with intertemporal substitution (see above). ${ }^{38}$

\footnotetext{
${ }^{37}$ It is less clear why Friend and Blume do not find strong evidence that the coefficient is far greater than unity, although the difference between stock market volatility and consumption covariance as a risk measure is no doubt the most important reason. Pindyck (1988), using own-variance as the volatility measure for equities, estimates relative risk aversion to be in the range of three to four.

${ }^{38}$ Two early studies by Weber $(1970,1975)$ found coefficients of risk aversion of 1.3 to 7.7. Hansen and Singleton (1983) find relative risk aversion of about one when they use the time-series movements of interest rates and consumption. Fitting the cross-section of stock returns requires a much higher risk aversion. See Cochrane and Hansen (1992) for an overview of this literature and a discussion of what feature of the data drive the results.
} 
None of the above studies address individuals directly, and thus none consider heterogeneity in risk aversion across individuals and its possible covariation with demographic group, economic circumstances, etc. Shiller, Boycko, and Korobov (1992) report the results of a survey question quite similar to ours. They asked a small sample of respondents from different countries whether they would be willing to take a job at a 50 percent higher wage than their current job if there were a 50-50 chance of failing at the job. In the event of failure, the respondent would get his or her old job back "after some time." Since the bad outcome entails only a temporary loss, this proposition is much less risky than ours. (The aim is to elicit jobmarket flexibility, not risk tolerance.) They find that fifty to eighty percent of respondents would take the new job, with Russians and West Germans less willing to take the new job than those in the United States. The unwillingness of many to face even a temporary income loss for the chance of a large, permanent gain would imply a high level of risk aversion.

Binswanger and associates ${ }^{39}$ address experimentally the level of risk aversion in rural India and Latin America. Researchers asked participants in the studies to choose among simple Bernoullian gambles in which the alternatives with larger spreads also bore higher expected payoffs. The flip of a coin then determined a reward, which was actually paid out to the respondents. The scale of the gambles was initially small, but the investigators expanded it over the duration of the study (which amounted to several weeks), until the payoffs were comparable to the returns from individual agricultural investments. Unlike the gambles we offer, Binswanger's were still small in relation to lifetime income. Binswanger's

${ }^{39}$ See Binswanger (1980), Binswanger and Sillers (1983), and the references therein. 
procedure has the advantage, however, of using actual rather than hypothetical risks.

Qualitatively speaking, Binswanger's results have been replicated subsequent investigators who repeated his experiments in a number of developing rural societies. ${ }^{40}$ They are also reasonably consistent with our findings. First, Binswanger and his associates find that both risk neutral to risk-loving behavior and "extreme" risk aversion were relatively uncommon. Some 80 percent of the respondents revealed risk aversion in the "moderate range." Second, the results were strikingly similar across the countries studied. Third, and perhaps of most direct relevance to the present paper, systematic heterogeneity within a population is rather limited. In particular, there is no discernable difference between wealthy and poor individuals in measured risk aversion.

Ramaswami, Srivastava, and McInish (1992) and McInish, Ramaswami, and Srivastava (1993) asked 3,000 households to keep a financial diary. Their survey also included both attitudinal questions and questions about finacial risk-return tradeoffs from which risk aversion was inferred. The 1992 paper concludes that net worth and income are both negatively related to risk aversion. The 1993 paper shows that, in their sample, a number of portfolio decisions are systematically related to declared household objectives (such as relative importance placed on education, retirement, etc.) and such investor characteristics as wealth, the stage of the life cycle, and risk aversion. The declared objectives are, in turn, also related to wealth, the life cycle, and risk aversion.

\footnotetext{
${ }^{40} \mathrm{Binswanger}$ and Sillers (1983) for a summary of the various studies, a number of which were in Latin America.
} 


\section{B. Intertemporal Substitution and Time Preference}

Recall that in the setup rigorously implied by theory that is the basis of our treatment of intertemporal choice, the degree of intertemporal substitution and the rate of time preference are determined jointly by solving two equations in two unknowns. Existing empirical work based on hypothetical survey responses about intertemporal choice focuses almost exclusively on the subjective rate of time preference. ${ }^{41}$

In econometric work based on household-level data, Hausman (1979) studies the tradeoff between purchase prices and operating efficiency of consumer durables. He finds very high rates of time preference, on the order of 25 percent per year. Lawrance (1991) estimates a consumption Euler equation for individuals in the PSID and also finds very high rates of time preference. She allows for heterogeneity in the sense that the discount rate is permitted to differ between rich and poor households, and along other demographic lines as well. Lawrance estimates a subjective rate of time preference for poor households that is three to five percentage points higher for households in the low permanent income group than those in the high permanent income group. She then controls for education and race, and finds that the gap in estimated time preference between rich and poor widens to a maximum of seven percentage points. All of Lawrance's estimates of time preference are high, being in the range of 12 to 19 percent. Although she does not emphasize this point, her estimates also find heterogeneity in the

\footnotetext{
"In contrast, econometric studies using the consumption Euler equation treat both time preference and the elasticity of intertemporal substitution. For example, Hall (1988) presents evidence that the responsiveness of consumption growth to real interest rates in the post-World War II U.S. time series yields an estimate of the elasticity of intertemporal substitution of close to zero. Also see above (Section III.E).
} 
elasticity of intertemporal substitution. For low income groups, it is about half as high as for high income groups.

Our finding of slightly negative time preference (yielding a positive slope of the consumption path at a zero interest rate) differs substantially from the high positive time preference rates found by Hausman and Lawrance. Instead, our estimates confirm a long series of papers in the "psychological" economics literature that find negative time preference. ${ }^{42}$ These studies find, for instance, that individuals typically prefer to get painful or boring tasks "over with," deferring more enjoyable tasks until later. Many of these studies actually look at individuals' implicit interest rates and thus are not able to distinguish between pure time preference and differences in opportunities to borrow and lend in imperfect capital markets. Maital and Maital (1977), West (1978), and Thaler (1981) all offered respondents choices between a given amount of money now and a larger amount in the future. ${ }^{43}$

Future research is needed to explain why the econometric and experimental evidence arrive at different conclusions. One possible explanation of the finding of high subjective discount rates in the econometric work is the difficulty of controlling for features of the economic environment facing agents, such as liquidity constraints and the need for precautionary savings.

\footnotetext{
${ }^{42}$ See Loewenstein (1987), Loewenstein and Prelec (1991, 1992), Loewenstein and Thaler (1989), Maital (1988), and Maital and Maital (1977).

${ }^{43}$ Thaler (1981) offered the choice between a payment one year from now and a payment two years later, and also increased the length of the time until repayment. He found that both of these variations lowered the implicit discount rate per unit time, and concluded that there is a psychic fixed cost to waiting, in addition to the variable cost which is proportional to the length of the interval. Fuchs (1982) provides a valuable unifying discussion of these papers and the related literature.
} 


\section{v. Summary}

The paper reports the results of experimental questions designed to elicit measures of risk tolerance, the elasticity of intertemporal substitution, and time preference. The measures concern preferences over behaviors that are central to macroeconomics and finance, namely willingness to take gambles over lifetime income and to substitute consumption over long periods. The parameters are estimated as part of the Health and Retirement Survey. Estimating the preference parameters as part of a large-scale survey has several advantages. First, the estimated preference parameters can be related to the behaviors that they should predict. The economics profession is skeptical about subjective questions and answers. The possibility of relating the subjectively estimated preference parameters to tangible behavior should address some of this skepticism. Second, to the extent that the estimated parameters do predict behavior, they might be useful in many applications of the survey database.

We find that there is substantial heterogeneity in preference parameters. Although most of our respondents are in our least risk tolerant category, many are substantially more risk tolerant. Very different behavior toward risk would be predicted for agents with these varying degree of risk tolerance. We have some success in relating these estimates to different behaviors. For example, the risk tolerance measure is related in the way one would expect to whether a respondent smokes, drinks heavily, has no health or life insurance, or holds stocks and other risky assets. Indeed, for virtually every behavior we investigate, the risk tolerance measure made qualitatively correct predictions. Yet, the amount of variation in behavior predicted by the preference parameter is quite small. The behaviors we seek to explain 
have substantial individual heterogeneity, only a small part of which is correlated with our measures.

The results for the intertemporal substitution parameter are more tentative because they are based on a pilot study on a very small sample. In this sample, the average elasticity of intertemporal substitution is close to zero. There is also some heterogeneity in the measures of the elasticity of intertemporal substitution. Moreover, respondent by respondent, the two parameters are essentially independent. 


\section{References}

Barsky, Robert, "Why Don't the Prices of Stocks and Bonds Move Together?" American Economic Review 79 (Dec. 1989) 1132-1145.

Binswanger, Hans P. "Attitudes toward Risk: Experimental Measurement in Rural India," American Journal of Agricultural Economics 62 (1980) 395-407.

and Donald A. Sillers, "Risk Aversion and Credit Constraints in Farmers' Decision-Making: A Reinterpretation" Journal of Development Studies 20 (Oct. 1983) 5-21.

Breeden, Douglas T., “An Intertemporal Asset Pricing Model with Stochastic Consumption and Investment Opportunities," Journal of Financial Economics 7 (1979) 265-296.

Brown, Charles C., "Equalizing Differences in the Labor Market," Quarterly Journal of Economics 94 (Feb. 1980) 113-134.

Campbe11, John Y. and John H. Cochrane, "By Force of Habit: A ConsumptionBased Explanation of Aggregate Stock Market Behavior," National Bureau of Economic Research Working Paper No. 4995 (January 1995).

Carro11, Christopher D., "How Does Future Income Affect Current Consumption?" Quarterly Journal of Economics 109 (1994) 111-147.

Cochrane, John H. and Lars P. Hansen, "Asset Pricing Explorations for Macroeconomics," NBER Macroeconomics Annual 7 (1992) 115-165.

Epstein, Larry G. and Stanley E. Zin, "Substitution, Risk Aversion, and the Temporal Behavior of Consumption and Asset Returns, "Econometrica 46 (1989) 185-200.

Friedman, Bernard, "Risk Aversion and the Consumer Choice for Health Insurance," Review of Economics and Statistics 56 (May 1973) 209-214.

Friedman, Milton, A Theory of the Consumption Function. Princeton: Princeton University Press, 1957.

Friend, Irwin, and Marshall E. Blume, "The Demand for Risky Assets," American Economic Review 65 (Dec. 1975) 900-922.

Fuchs, Victor R. "Time Preference and Health: An Exploratory Study," in Fuchs, ed. Economic Aspects of Health. Chicago: University of Chicago Press, 1982 .

Grossman, Sanford and Robert Shiller, "Determinants of the Variability of Stock Prices," American Economic Review 71 (1981) 222-227.

Ha11, Robert E., "Intertemporal Substitution in Consumption," Journal of Political Economy 96 (1988) 339-57. 
Hansen, Lars P. and Kenneth J. Singleton, "Stochastic Consumption, Risk Aversion, and the Temporal Behavior of Stock Market Returns," Journal of Political Economy 91 (1983) 249-265.

Hausman, Jerry A., "Individual Discount Rates and the Purchase and Utilization of Energy-Using Durables," Bell Journal of Economics 10 (Spring 1979) $33-54$.

Hi11, Danie1 H., "Respondent Rules and the Quality of Net Worth Data in the Health and Retirement Survey," Institute for Social Research, Health and Retirement Study Working Paper No. 94-002, December 1993.

Kimbal1, Miles and Philippe Weil, "Precautionary Saving and Consumption Smoothing Across Time and Possibilities," NBER Working Paper No. 3976 (January 1992).

Lawrance, Emily C., "Poverty and the Rate of Time Preference: Evidence from Panel Data, Journal of Political Economy 99 (Feb. 1991) 54-77

Loewenstein, George, "Anticipation and the Valuation of Delayed Consumption," Economic Journal 97 (Sept. 1987) 666-84.

and Drazen Prelec, "Negative Time Preference," American Economic Review Papers and Proceedings 81 (May 1991) 347-352.

and , "Anomalies in Intertemporal Choice: Evidence and an Interpretation," Quarterly Journal of Economics 107 (May 1992) 573-597.

and Richard H. Thaler, "Anomalies: Intertemporal Choice," Journal of Economic Perspectives 3 (Fall 1989) 181-193.

Maital, Shlomo, ed. Applied Behavioral Economics. New York: New York University Press, 1988.

Maital, Shlomo and Sharona Maital, "Time Preference, Delay, and Gratification and the Intergenerational Transmission of Economic Inequality: A Behavioral Theory of Income Distribution," in Orley P. Ashenfelter and Wallace E. Oates, eds., Essays in Labor Market Analysis in Memory of Yochanan Peter Comay. New York: Wiley, 1977.

Mankiw, N. Gregory, "The Permanent Income Hypothesis and the Real Interest Rate," Economics Letters 7 (1981) 307-311.

, Julio J. Rotemberg, and Lawrence H. Summers, "Intertemporal Substitution in Macroeconomics," Quarterly Journal of Economics 100 (1985) $225-233$.

and Stephen P. Zeldes, "The Consumption of Stockholders and NonStockholders," Journal of Financial Economics 29 (1991) 97-112.

McInish, Thomas H., Sridhar N. Ramaswami, and Rajendra K. Srivastava, "Do More Risk-Averse Investors Have Lower Net Worth and Income?" Financial Review 28 (Feb. 1993) 91-106. 
Mehra, R. and Edward C. Prescott, "The Equity Premium: A Puzzle," Journal of Monetary Economics 15 (1985) 145-161.

Pindyck, Robert S. "Risk Aversion and Determinant of Stock Market Behavior", Review of Economics and Statistics 70 (May 1988) 183-190.

Ramaswami, Sridhar N., Rajendra K. Srivastava, and Thomas H. McInish, Journal of Economic Behavior and Organization 19 (Dec. 1992) 285-306.

Selden, L., "A New Representation of Preferences over 'Certainty X Uncertainty' Consumption Pairs: The 'Ordinal Certainty Equivalence' Hypothesis," Econometrica 46 (1978) 1045-1060.

Shiller, Robert J., Maxim Boycko, and Vladimir Korobov, "Hunting for Homo Sovieticus: Situational versus Attitudinal Factors in Economic Behavior," Brookings Papers on Economics Activity (1:1992) 127-181.

Szpiro George G., "Measuring Risk Aversion: An Alternative Approach," Review of Economics and Statistics 68 (Feb. 1986) 159-169.

Thaler, Richard H., "Some Empirical Evidence on Dynamic Inconsistency," Economics Letters 8 (1981) 201-207. Reprinted in Quasi-Rational Economics. New York: Russe11 Sage, 1991.

Viscusi, W. Kip and William N. Evans, "Utility Functions that Depend on Health Status: Estimates and Economic Implications," American Economic Review 80 (June 1990) 353-374.

Weber, Warren E., "The Effects of Interest Rates on Aggregate Consumption," American Economic Review 60 (Sept. 1970) 591-600.

, “Interest Rates, Inflation, and Consumer Expenditures," American Economic Review 65 (Dec. 1975) 843-858.

Weil, Philippe, "Nonexpected Utility in Macroeconomics," Quarterly Journal of Economics 105 (Feb. 1990) 29-42.

West, Richard W., "The Rate of Time Preference of Families in the Seattle and Denver Income Maintenance Experiment," Research Memorandum 51, SRI International (1978). 
Table 1

Risk Aversion Survey Gambles

\begin{tabular}{|c|c|c|c|c|c|}
\hline \multirow[t]{2}{*}{ Gamble $\mathbf{a}^{a}$} & \multicolumn{2}{|c|}{$\begin{array}{c}\text { Relative Rigk } \\
\text { Avergion }\end{array}$} & \multicolumn{3}{|c|}{$\begin{array}{c}\text { Relative Risk } \\
\text { Tolerance }\end{array}$} \\
\hline & $\begin{array}{l}\text { Upper } \\
\text { Bound }\end{array}$ & $\begin{array}{l}\text { Lower } \\
\text { Bound }\end{array}$ & $\begin{array}{l}\text { Lower } \\
\text { Bound }\end{array}$ & $\begin{array}{l}\text { Opper } \\
\text { Bound } \\
\end{array}$ & Mean \\
\hline $\begin{array}{l}\text { I. Reject both one- } \\
\text { third and one-fifth }\end{array}$ & $\infty$ & 3.76 & 0 & 0.27 & 0.11 \\
\hline $\begin{array}{l}\text { II. Reject one-third but } \\
\text { accept one-fifth }\end{array}$ & 3.76 & 2 & 0.27 & 0.5 & 0.36 \\
\hline $\begin{array}{l}\text { III. Accept one-third but } \\
\text { reject one-half }\end{array}$ & 2 & 1 & 0.5 & 1 & 0.68 \\
\hline $\begin{array}{l}\text { IV. Accept both one- } \\
\text { third and one-half }\end{array}$ & 1 & 0 & 1 & $\infty$ & 1.61 \\
\hline \multicolumn{6}{|c|}{$\begin{array}{l}a_{G a m b l e s} \text { all have a } 50 \text { percent probability of doubling lifetime } \\
\text { income and a } 50 \text { percent probability of losing half, one-third, or one- } \\
\text { fifth of lifetime income. }\end{array}$} \\
\hline
\end{tabular}

Table 2. Bxpectation of Relative Risk Tolerance Conditional on Survey Response

\begin{tabular}{|l|c|c|c|c|}
\hline & I & II & III & IV \\
\hline Expected Risk Tolerance & 0.15 & 0.28 & 0.35 & 0.57 \\
\hline Bxpected Risk Aversion & 15.7 & 7.2 & 5.7 & 3.8 \\
\hline
\end{tabular}

Note: This table shows the expected value of relative risk tolerance and relative risk aversion conditional on observing response I, II, III, or IV. This conditional expectation takes into account measurement error in the survey response (gee text for details of the calculation.) In contrast, the last column of Table 1 ghows the average of the true parameter conditional on it being between the upper and lower bounds. Expected risk aversion is not the reciprocal of expected risk tolerace owing to Jensen's inequality. 
Table 3. Risk Tolerance by Groups:

Row Percentages, Total Reeponses, and Kean Risk Tolerance

3-A. All Respondents

\begin{tabular}{|l|c|c|c|c|c|c|}
\hline & I & II & III & IV & N & $\begin{array}{c}\text { Mean Risk } \\
\text { Tolerance }\end{array}$ \\
\hline $\begin{array}{l}\text { All } \\
\text { Respondents }\end{array}$ & 64.6 & 11.6 & 10.9 & 12.8 & 11707 & $\begin{array}{c}0.2412 \\
(0.0013)\end{array}$ \\
\hline
\end{tabular}

3-B. Primary (R1) and Secondary (R2) Respondents

\begin{tabular}{|l|c|c|c|c|c|c|c|}
\hline & I & II & III & IV & N & $\begin{array}{c}\text { Yean Rigk } \\
\text { Tolerance }\end{array}$ & p-value \\
\hline R1 only & 64.8 & 11.4 & 10.7 & 13.0 & 7278 & $\begin{array}{c}0.2413 \\
(0.0017)\end{array}$ & 0.9201 \\
\hline R2 only & 64.3 & 11.8 & 11.2 & 12.5 & 4429 & $\begin{array}{c}0.2410 \\
(0.0021)\end{array}$ & \\
\hline
\end{tabular}

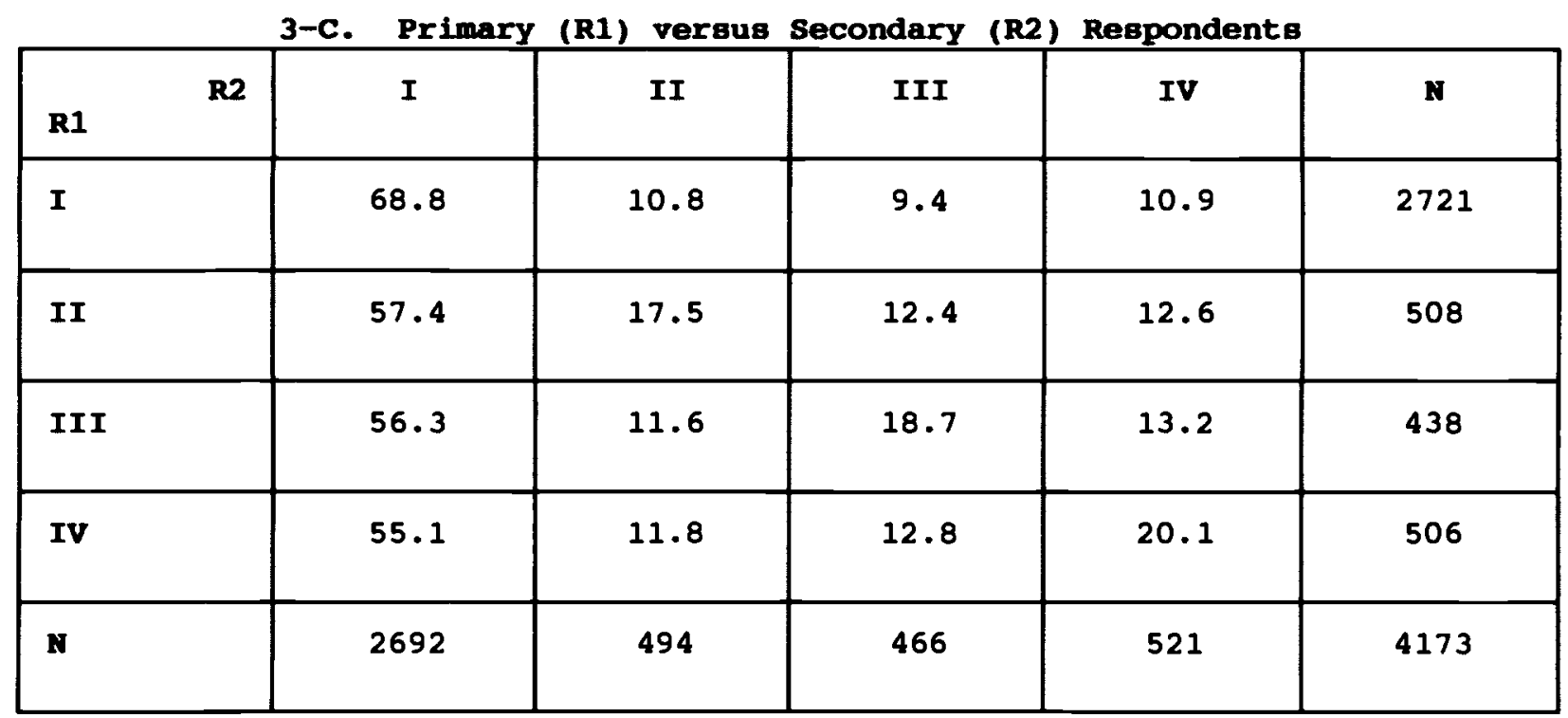

Note: Sample limited to households with both a primary and secondary respondent. Rows give R2's risk tolerance conditional on R1'B risk tolerance. 
3-D. Age Groups

\begin{tabular}{|c|c|c|c|c|c|c|c|}
\hline & I & II & III & IV & N & $\begin{array}{c}\text { Mean Risk } \\
\text { Tolerance }\end{array}$ & p-value \\
\hline Under 50 & 58.5 & 14.4 & 13.8 & 13.1 & 1147 & $\begin{array}{c}0.2542 \\
(0.0044)\end{array}$ \\
\hline $50-54$ & 61.9 & 12.0 & 12.2 & 13.7 & 3800 & $\begin{array}{c}0.2486 \\
(0.0024)\end{array}$ \\
\hline $55-59$ & 66.0 & 11.5 & 9.8 & 12.5 & 4061 & $\begin{array}{c}0.2372 \\
(0.0023)\end{array}$ \\
\hline $60-64$ & 69.3 & 9.5 & 9.4 & 11.6 & 2170 & $\begin{array}{c}0.2301 \\
(0.0030)\end{array}$ \\
\hline $65-69$ & 66.6 & 12.0 & 9.2 & 12.0 & 390 & $\begin{array}{c}0.2331 \\
(0.0070)\end{array}$ \\
\hline Over 70 & 68.3 & 6.4 & 9.3 & 15.8 & 139 & $\begin{array}{c}0.2432 \\
(0.0131)\end{array}$ \\
\hline
\end{tabular}

\begin{tabular}{|l|c|c|c|c|c|c|c|}
\hline & I & II & III & IV & N & $\begin{array}{c}\text { Mean Risk } \\
\text { Tolerance }\end{array}$ & p-value \\
\hline Female & 65.1 & 11.8 & 11.0 & 11.9 & 6448 & $\begin{array}{c}0.2383 \\
(0.0017)\end{array}$ & 0.0166 \\
\cline { 1 - 2 } & 64.0 & 11.2 & 10.7 & 13.9 & 5259 & $\begin{array}{c}0.2448 \\
(0.0020)\end{array}$ \\
\hline
\end{tabular}


3-P. Race

\begin{tabular}{|c|c|c|c|c|c|c|c|}
\hline & $\mathbf{I}$ & II & III & IV & $\mathbf{N}$ & $\begin{array}{l}\text { Mean Risk } \\
\text { Tolerance }\end{array}$ & p-value \\
\hline Thite & 64.9 & 12.5 & 10.7 & 11.8 & 8508 & $\begin{array}{c}0.2377 \\
(0.0015)\end{array}$ & \multirow{5}{*}{0.0001} \\
\hline Black & 66.7 & 9.1 & 10.6 & 13.3 & 1884 & $\begin{array}{c}0.2402 \\
(0.0034)\end{array}$ & \\
\hline $\begin{array}{l}\text { American } \\
\text { Indian, } \\
\text { Alaskan }\end{array}$ & 62.3 & 10.0 & 13.7 & 13.7 & 109 & $\begin{array}{c}0.2462 \\
(0.0143)\end{array}$ & \\
\hline Asian & 57.9 & 10.3 & 11.1 & 20.6 & 126 & $\begin{array}{c}0.2762 \\
(0.0165)\end{array}$ & \\
\hline Hispanic & 59.3 & 9.2 & 12.6 & 18.7 & 1054 & $\begin{array}{c}0.2666 \\
(0.0050)\end{array}$ & \\
\hline
\end{tabular}

3-G. Religion

\begin{tabular}{|l|c|c|c|c|c|c|c|}
\hline & I & II & III & IV & N & $\begin{array}{c}\text { Mean Riøk } \\
\text { Tolerance }\end{array}$ & p-value \\
\hline Protestant & 66.2 & 11.5 & 10.8 & 11.4 & 7404 & $\begin{array}{c}0.2350 \\
(0.0016)\end{array}$ \\
\hline Catholic & 62.3 & 10.8 & 11.4 & 15.3 & 3185 & $\begin{array}{c}0.2514 \\
(0.0027)\end{array}$ & 0.0001 \\
\hline Jewish & 56.3 & 13.2 & 11.1 & 19.2 & 197 & $\begin{array}{c}0.2683 \\
(0.0113)\end{array}$ \\
\hline Other & 61.6 & 14.3 & 9.6 & 14.3 & 900 & $\begin{array}{c}0.2498 \\
(0.0051)\end{array}$ \\
\hline
\end{tabular}

3-H. Smoking

\begin{tabular}{|l|c|c|c|c|c|c|c|}
\hline & I & II & III & IV & N & $\begin{array}{c}\text { Mean Risk } \\
\text { Tolerance }\end{array}$ & p-value \\
\hline $\begin{array}{l}\text { Never } \\
\text { Smoked }\end{array}$ & 66.3 & 11.2 & 10.9 & 11.4 & 4276 & $\begin{array}{c}0.2353 \\
(0.0021)\end{array}$ \\
\hline Quit & 63.9 & 11.9 & 11.2 & 12.9 & 4276 & $\begin{array}{c}0.2425 \\
(0.0022)\end{array}$ & 0.0017 \\
\hline $\begin{array}{l}\text { Smokes } \\
\text { Now }\end{array}$ & 63.3 & 11.6 & 10.4 & 14.5 & 3155 & $\begin{array}{c}0.2474 \\
(0.0027)\end{array}$ & \\
\hline
\end{tabular}

See notes at end of table. 
3-I. Drinke

\begin{tabular}{|l|c|c|c|c|c|c|c|}
\hline & I & II & III & IV & N & $\begin{array}{c}\text { Mean Risk } \\
\text { Tolerance }\end{array}$ & p-value \\
\hline No & 68.0 & 9.4 & 10.2 & 12.1 & 4584 & $\begin{array}{c}0.2344 \\
(0.0021)\end{array}$ & 0.0001 \\
Yes & 62.4 & 12.9 & 11.3 & 13.2 & 7123 & $\begin{array}{c}0.2456 \\
(0.0017)\end{array}$ \\
\hline
\end{tabular}

3-J. Drinke per Day

\begin{tabular}{|l|c|c|c|c|c|c|c|}
\hline & I & II & III & IV & N & $\begin{array}{c}\text { Mean Rigk } \\
\text { Tolerance }\end{array}$ & p-value \\
\hline 0 & 68.0 & 9.4 & 10.2 & 12.1 & 4584 & $\begin{array}{c}0.2344 \\
(0.0021)\end{array}$ \\
\hline$<1$ & 63.2 & 12.9 & 11.5 & 12.2 & 5317 & $\begin{array}{c}0.2418 \\
(0.0019)\end{array}$ & 0.0001 \\
\hline $1-2$ & 59.5 & 13.4 & 11.5 & 15.4 & 1187 & $\begin{array}{c}0.2549 \\
0.0044)\end{array}$ \\
\hline $3-4$ & 61.9 & 11.7 & 9.0 & 17.2 & 441 & $\begin{array}{c}0.2573 \\
(0.0078)\end{array}$ \\
\hline
\end{tabular}

3-K. Years of Bducation

\begin{tabular}{|l|c|c|c|c|c|c|c|}
\hline & I & II & III & IV & N & $\begin{array}{c}\text { Mean Risk } \\
\text { Tolerance }\end{array}$ & p-value \\
\hline $0-11$ & 65.7 & 8.9 & 10.8 & 14.4 & 3320 & $\begin{array}{c}0.2448 \\
(0.0026)\end{array}$ & 0.0001 \\
\hline 12 & 67.7 & 11.4 & 10.5 & 10.2 & 4130 & $\begin{array}{c}0.2294 \\
(0.0021)\end{array}$ & 0.2463 \\
\hline $13-16$ & 61.9 & 13.4 & 11.2 & 13.3 & 3158 & $0.0026)$ & 0.2598 \\
$(0.0046)$
\end{tabular}

See notes at end of table. 
3-L. Employment status

\begin{tabular}{|l|c|c|c|c|c|c|c|}
\hline & I & II & III & IV & N & $\begin{array}{c}\text { Mean Risk } \\
\text { Tolerance }\end{array}$ & p-value \\
\hline $\begin{array}{l}\text { Self- } \\
\text { Bmployed }\end{array}$ & 63.9 & 10.4 & 11.1 & 14.4 & 1374 & $\begin{array}{c}0.2461 \\
(0.0041)\end{array}$ \\
\hline $\begin{array}{l}\text { Works for } \\
\text { Somsone }\end{array}$ & 66.0 & 12.0 & 10.5 & 11.3 & 6397 & $\begin{array}{c}0.2349 \\
(0.0017)\end{array}$ & 0.0001 \\
\hline $\begin{array}{l}\text { Not } \\
\text { Working }\end{array}$ & 62.5 & 11.2 & 11.4 & 14.7 & 3936 & $\begin{array}{c}0.2497 \\
(0.0024)\end{array}$ & \\
\hline
\end{tabular}

3-X. Health Insurance

\begin{tabular}{|c|c|c|c|c|c|c|c|c|}
\hline $\begin{array}{l}\text { Works } \\
\text { for }\end{array}$ & $\begin{array}{l}\text { Any } \\
\text { form of } \\
\text { Health } \\
\text { Ins.? }\end{array}$ & I & II & III & IV & $\mathbf{x}$ & $\begin{array}{l}\text { Hean } \\
\text { of Risk } \\
\text { Tolerance }\end{array}$ & $\begin{array}{l}\mathbf{P}- \\
\text { Value }\end{array}$ \\
\hline \multirow[t]{2}{*}{$\begin{array}{l}\text { Him/ } \\
\text { Herself }\end{array}$} & Yes & 63.5 & 10.0 & 12.3 & 14.0 & 763 & $\begin{array}{c}0.2459 \\
(0.0055)\end{array}$ & \multirow{2}{*}{0.4953} \\
\hline & No & 63.0 & 10.3 & 10.0 & 16.6 & 319 & $\begin{array}{c}0.2529 \\
(0.0089)\end{array}$ & \\
\hline \multirow[t]{2}{*}{$\begin{array}{l}\text { Someone } \\
\text { else }\end{array}$} & Yes & 66.9 & 11.8 & 10.5 & 10.6 & 4186 & $\begin{array}{c}0.2317 \\
(0.0021)\end{array}$ & \multirow{2}{*}{0.0001} \\
\hline & No & 58.4 & 11.4 & 13.4 & 16.6 & 638 & $\begin{array}{c}0.2643 \\
(0.0063)\end{array}$ & \\
\hline \multirow[t]{2}{*}{$\begin{array}{l}\text { Doesn't } \\
\text { Work }\end{array}$} & $\mathbf{Y e s}$ & 63.8 & 11.9 & 10.9 & 13.2 & 1343 & $\begin{array}{c}0.2424 \\
(0.0039)\end{array}$ & \multirow{2}{*}{0.0002} \\
\hline & No & 59.8 & 10.1 & 12.0 & 18.0 & 1393 & $\begin{array}{c}0.2647 \\
(0.0043)\end{array}$ & \\
\hline
\end{tabular}

Note: Excludes Medicare-eligible individuals.

3-N. Life Insurance

\begin{tabular}{|l|c|c|c|c|c|c|c|}
\hline & I & II & III & IV & N & $\begin{array}{c}\text { Mean Risk } \\
\text { Tolerance }\end{array}$ & p-value \\
\cline { 1 - 2 } No & 61.0 & 11.5 & 11.7 & 15.7 & 3399 & $\begin{array}{c}0.2548 \\
(0.0026)\end{array}$ & 0.0001 \\
\cline { 1 - 2 } & 66.1 & 11.6 & 10.5 & 11.6 & 8162 & $\begin{array}{c}0.2353 \\
(0.0015)\end{array}$ \\
\hline
\end{tabular}

see notes at end of table. 
3-0. Region

\begin{tabular}{|l|c|c|c|c|c|c|c|}
\hline & I & II & III & IV & N & $\begin{array}{c}\text { Mean Rigk } \\
\text { Tolerance }\end{array}$ & P-value \\
\hline $\begin{array}{l}\text { Non- } \\
\text { Weaterner }\end{array}$ & 65.5 & 11.2 & 10.7 & 12.4 & 9811 & $\begin{array}{c}0.2388 \\
(0.0014)\end{array}$ & 0.0001 \\
\cline { 1 - 3 } Nesterner & 59.8 & 13.1 & 11.9 & 14.9 & 1896 & $\begin{array}{c}0.2538 \\
(0.0035)\end{array}$ \\
\hline
\end{tabular}

3-P. Immigration status

\begin{tabular}{|l|c|c|c|c|c|c|c|}
\hline & I & II & III & IV & N & $\begin{array}{c}\text { Mean Risk } \\
\text { Tolerance }\end{array}$ & p-value \\
\hline Kative & 65.0 & 11.9 & 10.8 & 12.2 & 10568 & $\begin{array}{c}0.2389 \\
(0.0014)\end{array}$ & 0.0001 \\
\cline { 1 - 2 } & 61.2 & 8.2 & 11.7 & 18.7 & 1139 & $\begin{array}{c}0.2630 \\
(0.0049)\end{array}$ \\
\hline
\end{tabular}

Note: Immigrants are defined as persons not born in the United states.

3-Q. Family Income quintiles

\begin{tabular}{|l|c|c|c|c|c|c|c|}
\hline & I & II & III & IV & N & $\begin{array}{c}\text { Mean Risk } \\
\text { Tolerance }\end{array}$ & p-value \\
\hline Ist & 62.2 & 9.3 & 12.3 & 16.1 & 2415 & $\begin{array}{c}0.2556 \\
0.0032)\end{array}$ \\
\hline 2nd & 66.7 & 10.5 & 10.5 & 12.1 & 2321 & $\begin{array}{c}0.2366 \\
(0.0030)\end{array}$ \\
\hline 3rd & 66.9 & 11.6 & 10.5 & 10.8 & 2289 & $\begin{array}{c}0.2310 \\
0.0028)\end{array}$ & 0.0001 \\
\hline 4th & 67.2 & 12.3 & 9.1 & 11.2 & 2356 & $\begin{array}{c}0.2312 \\
0.0028)\end{array}$ \\
\hline 5th & 59.9 & 14.4 & 12.1 & 13.7 & 2326 & $\begin{array}{c}0.2511 \\
(0.0030)\end{array}$ \\
\hline
\end{tabular}

Note: Cut-offs for the quintiles are $\$ 18,980, \$ 33,200, \$ 49,000$, and $\$ 72,200$.

see noter at end of table. 
3-R. Net Worth Quintiles

\begin{tabular}{|l|c|c|c|c|c|c|c|}
\hline & I & II & III & IV & N & $\begin{array}{c}\text { Mean Rigk } \\
\text { Tolerance }\end{array}$ & p-value \\
\hline I8t & 61.5 & 9.1 & 12.0 & 17.2 & 2402 & $\begin{array}{c}0.2601 \\
(0.0033)\end{array}$ \\
\hline 2nd & 65.0 & 12.0 & 10.7 & 12.1 & 2320 & $\begin{array}{c}0.2381 \\
(0.0029)\end{array}$ \\
\hline 3rd & 67.4 & 11.5 & 10.2 & 11.2 & 2335 & $\begin{array}{c}0.2318 \\
(0.0029)\end{array}$ \\
\hline 4th & 65.7 & 12.7 & 11.4 & 10.0 & 2319 & $\begin{array}{c}0.2319 \\
(0.0028)\end{array}$ \\
\hline 5th & 63.4 & 13.1 & 10.0 & 13.3 & 2331 & $\begin{array}{c}0.2435 \\
(0.0030)\end{array}$ \\
\hline
\end{tabular}

Note: Net worth includes housing wealth. Cut-offs for the quintiles are $\$ 21,000, \$ 70,000, \$ 139,000$, and $\$ 285,000$.

3-s. Home Ownership

\begin{tabular}{|l|c|c|c|c|c|c|c|}
\hline & I & II & III & IV & N & $\begin{array}{c}\text { Mean Risk } \\
\text { Tolerance }\end{array}$ & p-value \\
\hline No & 60.3 & 10.0 & 12.3 & 17.2 & 2287 & $\begin{array}{c}0.2618 \\
(0.0034)\end{array}$ & 0.0001 \\
\cline { 1 - 2 } & 65.6 & 11.9 & 10.5 & 11.7 & 9420 & $\begin{array}{c}0.2362 \\
(0.0014)\end{array}$ \\
\hline
\end{tabular}

3-T. Business Ownership

\begin{tabular}{|l|c|c|c|c|c|c|c|}
\hline & I & II & III & IV & N & $\begin{array}{c}\text { Hean Risk } \\
\text { Tolerance }\end{array}$ & p-value \\
\hline No & 65.1 & 11.3 & 10.7 & 12.7 & 9655 & $\begin{array}{c}0.2402 \\
(0.0014)\end{array}$ & 0.1246 \\
\cline { 1 - 2 } & 62.3 & 12.5 & 11.9 & 13.1 & 2052 & $\begin{array}{c}0.2457 \\
(0.0032)\end{array}$ & \\
\hline
\end{tabular}

See notes at end of table. 
3-0. stock Ownership

\begin{tabular}{|l|c|c|c|c|c|c|c|}
\hline & I & II & III & IV & N & $\begin{array}{c}\text { Mean Risk } \\
\text { Tolerance }\end{array}$ & p-value \\
\hline No & 65.4 & 11.0 & 10.6 & 12.8 & 8308 & $\begin{array}{c}0.2401 \\
(0.0016)\end{array}$ & 0.2132 \\
\cline { 1 - 2 } & 62.6 & 12.9 & 11.5 & 12.7 & 3399 & $\begin{array}{c}0.2439 \\
(0.0025)\end{array}$ \\
\hline
\end{tabular}

3-V. Bond Owmership

\begin{tabular}{|l|c|c|c|c|c|c|c|}
\hline & I & II & III & IV & N & $\begin{array}{c}\text { Mean Risk } \\
\text { Tolerance }\end{array}$ & p-value \\
\hline Ko & 65.0 & 11.2 & 10.8 & 12.8 & 10960 & $\begin{array}{c}0.2406 \\
(0.0014)\end{array}$ \\
\cline { 1 - 2 } & 58.2 & 17.0 & 11.9 & 12.8 & 747 & $\begin{array}{c}0.2495 \\
(0.0052)\end{array}$ \\
\hline
\end{tabular}

3-W. Saving/Checking Account Ownerghip

\begin{tabular}{|l|c|c|c|c|c|c|c|}
\hline & I & II & III & IV & N & $\begin{array}{c}\text { Kean Risk } \\
\text { Tolerance }\end{array}$ & p-value \\
\hline No & 62.3 & 8.7 & 12.4 & 16.4 & 2246 & $\begin{array}{r}0.2572 \\
(0.0034)\end{array}$ & 0.0001 \\
\hline Yes & 65.1 & 12.2 & 10.5 & 11.9 & 9461 & $\begin{array}{c}0.2374 \\
(0.0014)\end{array}$ & \\
\hline
\end{tabular}

3-x. Treasury Bill Ownership

\begin{tabular}{|l|c|c|c|c|c|c|c|}
\hline & I & II & III & IV & N & $\begin{array}{c}\text { Mean Risk } \\
\text { Tolerance }\end{array}$ & p-value \\
\hline No & 64.1 & 11.0 & 11.3 & 13.4 & 8594 & $\begin{array}{c}0.2442 \\
(0.0016)\end{array}$ & 0.0002 \\
\cline { 1 - 1 } & 65.8 & 13.2 & 9.8 & 11.0 & 3113 & $\begin{array}{c}0.2329 \\
(0.0025)\end{array}$ & \\
\hline
\end{tabular}

see notes at end of table. 
3-Y. IRA/Keogh Ownership

\begin{tabular}{|l|c|c|c|c|c|c|c|}
\hline & I & II & III & IV & N & $\begin{array}{c}\text { Mean Risk } \\
\text { Tolerance }\end{array}$ & p-value \\
\cline { 1 - 7 } No & 64.9 & 10.3 & 11.0 & 13.7 & 6983 & $\begin{array}{c}0.2441 \\
(0.0018)\end{array}$ & \multirow{2}{*}{0.0098} \\
\cline { 1 - 6 } & 64.1 & 13.5 & 10.7 & 11.5 & 4724 & $\begin{array}{c}0.2369 \\
(0.0020)\end{array}$ & \\
\hline
\end{tabular}

Notes for Table 2: The tables cross-tabulate the estimated risk tolerance of the respondents by variables indicated in headings. Columns headed I through IV give percent of respondents in each row in the the four risk tolerance categories (see Table). Column headed $\mathrm{N}$ is the number of respondent in each row. The mean risk tolerance is the mean of the numerical values of riak tolerance (see Table 2 and text). Standard error is in parentheses. The pvalue is for the E-statistic that the mean risk tolerance is equal across rows. Primary and secondary respondents are pooled. Number of observations differs owing to miseing data. 
Table 4

Regressions

\begin{tabular}{|c|c|c|c|c|}
\hline & $\begin{array}{c}\text { Bver Smoke } \\
\text { (i) }\end{array}$ & $\begin{array}{c}\text { smoke Now } \\
\text { (ii) }\end{array}$ & $\begin{array}{l}\text { Drink } \\
\text { (iii) }\end{array}$ & $\begin{array}{c}\text { Drinks per } \\
\text { Day } \\
\text { (iv) }\end{array}$ \\
\hline Intercept & $\begin{array}{c}0.5007 \\
(0.0452)\end{array}$ & $\begin{array}{c}0.5748 \\
(0.0425)\end{array}$ & $\begin{array}{c}0.8069 \\
(0.0455)\end{array}$ & $\begin{array}{c}1.1035 \\
(0.0805)\end{array}$ \\
\hline Age & $\begin{array}{c}0.0002 \\
(0.0008)\end{array}$ & $\begin{array}{l}-0.0062 \\
(0.0007)\end{array}$ & $\begin{array}{l}-0.0056 \\
(0.0008)\end{array}$ & $\begin{array}{l}-0.0097 \\
(0.0014)\end{array}$ \\
\hline Male & $\begin{array}{c}0.2016 \\
(0.0091)\end{array}$ & $\begin{array}{c}0.0461 \\
(0.0086)\end{array}$ & $\begin{array}{c}0.1438 \\
(0.0092)\end{array}$ & $\begin{array}{c}0.3947 \\
(0.0162)\end{array}$ \\
\hline Catholic & $\begin{array}{c}0.0528 \\
(0.0108)\end{array}$ & $\begin{array}{c}0.0140 \\
(0.0102)\end{array}$ & $\begin{array}{c}0.1890 \\
(0.0109)\end{array}$ & $\begin{array}{l}0.2325 \\
(0.0193)\end{array}$ \\
\hline Jewish & $\begin{array}{c}0.0458 \\
(0.0339)\end{array}$ & $\begin{array}{l}-0.0957 \\
(0.0319)\end{array}$ & $\begin{array}{c}0.2072 \\
(0.0342)\end{array}$ & $\begin{array}{c}0.1455 \\
(0.0605)\end{array}$ \\
\hline $\begin{array}{l}\text { Other } \\
\text { Religion }\end{array}$ & $\begin{array}{c}0.0410 \\
(0.0167)\end{array}$ & $\begin{array}{l}-0.0034 \\
(0.0157)\end{array}$ & $\begin{array}{c}0.0985 \\
(0.0168)\end{array}$ & $\begin{array}{c}0.1822 \\
(0.0298)\end{array}$ \\
\hline Black & $\begin{array}{c}0.0024 \\
(0.0121)\end{array}$ & $\begin{array}{c}0.0409 \\
(0.0114)\end{array}$ & $\begin{array}{l}-0.0678 \\
(0.0122)\end{array}$ & $\begin{array}{l}-0.0708 \\
(0.0217)\end{array}$ \\
\hline Aispanic & $\begin{array}{l}-0.1115 \\
(0.0162)\end{array}$ & $\begin{array}{l}-0.0433 \\
(0.0153)\end{array}$ & $\begin{array}{l}-0.2498 \\
(0.0164)\end{array}$ & $\begin{array}{l}-0.3360 \\
(0.0290)\end{array}$ \\
\hline Asian & $\begin{array}{l}-0.2868 \\
(0.0424)\end{array}$ & $\begin{array}{l}-0.1288 \\
(0.0399)\end{array}$ & $\begin{array}{l}-0.1541 \\
(0.0427)\end{array}$ & $\begin{array}{l}-0.3349 \\
(0.0756)\end{array}$ \\
\hline other Race & $\begin{array}{c}0.0232 \\
(0.0442)\end{array}$ & $\begin{array}{c}0.0998 \\
(0.0416)\end{array}$ & $\begin{array}{l}-0.2379 \\
(0.0445)\end{array}$ & $\begin{array}{l}-0.2456 \\
(0.0788)\end{array}$ \\
\hline $\begin{array}{l}\text { Risk } \\
\text { Tolerance }\end{array}$ & $\begin{array}{c}0.0922 \\
(0.0295)\end{array}$ & $\begin{array}{c}0.0679 \\
(0.0278)\end{array}$ & $\begin{array}{c}0.0993 \\
(0.0297)\end{array}$ & $\begin{array}{c}0.2557 \\
(0.0526)\end{array}$ \\
\hline $\mathbf{N}$ & 11707 & 11707 & 11707 & 11707 \\
\hline $\mathbf{R} \cdot \mathbf{M} \cdot \mathbf{s} \cdot \mathbf{E}$ & 0.4686 & 0.4414 & 0.4722 & 0.8353 \\
\hline R-squared & 0.0535 & 0.011 & 0.0646 & 0.0727 \\
\hline $\begin{array}{l}\text { Incremental } \\
\text { R-squared }\end{array}$ & 0.0008 & 0.0005 & 0.0008 & 0.0019 \\
\hline Mean Dep.Var. & 0.6347 & 0.2695 & 0.6084 & 0.8307 \\
\hline
\end{tabular}


Table 4 (continued)

\begin{tabular}{|c|c|c|c|c|}
\hline & $\begin{array}{c}\text { Education } \\
(v)\end{array}$ & $\begin{array}{l}\text { self } \\
\text { Enployed } \\
\text { (vi) }\end{array}$ & $\begin{array}{l}\text { No Health } \\
\text { Insurance } \\
\text { (vii) }\end{array}$ & $\begin{array}{l}\text { No Life } \\
\text { Insurance } \\
\text { ( } v i i i)\end{array}$ \\
\hline Intercept & $\begin{array}{l}15.7565 \\
(0.2817)\end{array}$ & $\begin{array}{c}0.1878 \\
(0.0306)\end{array}$ & $\begin{array}{c}0.3489 \\
(0.0549)\end{array}$ & $\begin{array}{c}0.2146 \\
(0.0427)\end{array}$ \\
\hline Age & $\begin{array}{l}-0.0604 \\
(0.0050)\end{array}$ & $\begin{array}{l}-0.0016 \\
(0.0005)\end{array}$ & $\begin{array}{l}-0.0031 \\
(0.0009)\end{array}$ & $\begin{array}{c}0.0008 \\
(0.0007)\end{array}$ \\
\hline Male & $\begin{array}{c}0.1786 \\
(0.0568)\end{array}$ & $\begin{array}{c}0.0748 \\
(0.0061)\end{array}$ & $\begin{array}{l}-0.0493 \\
(0.0093)\end{array}$ & $\begin{array}{l}-0.1291 \\
(0.0085)\end{array}$ \\
\hline Catholic & $\begin{array}{c}0.2606 \\
(0.0675)\end{array}$ & $\begin{array}{l}-0.0178 \\
(0.0073)\end{array}$ & $\begin{array}{l}-0.0268 \\
(0.0115)\end{array}$ & $\begin{array}{c}0.0050 \\
(0.0102)\end{array}$ \\
\hline Jewish & $\begin{array}{l}2.1437 \\
(0.2115)\end{array}$ & $\begin{array}{c}0.1054 \\
(0.0230)\end{array}$ & $\begin{array}{l}-0.0623 \\
(0.0370)\end{array}$ & $\begin{array}{c}0.0609 \\
(0.0321)\end{array}$ \\
\hline $\begin{array}{l}\text { Other } \\
\text { Religion }\end{array}$ & $\begin{array}{c}0.3859 \\
(0.1044)\end{array}$ & $\begin{array}{c}0.0339 \\
(0.0113)\end{array}$ & $\begin{array}{c}0.0871 \\
(0.0172)\end{array}$ & $\begin{array}{c}0.0729 \\
(0.0158)\end{array}$ \\
\hline Black & $\begin{array}{l}-1.2907 \\
(0.0758)\end{array}$ & $\begin{array}{l}-0.0628 \\
(0.0082)\end{array}$ & $\begin{array}{c}0.1872 \\
(0.0123)\end{array}$ & $\begin{array}{c}0.0554 \\
(0.0114)\end{array}$ \\
\hline Hispanic & $\begin{array}{l}-4.2541 \\
(0.1015)\end{array}$ & $\begin{array}{l}-0.0432 \\
(0.0110)\end{array}$ & $\begin{array}{c}0.3957 \\
(0.0165)\end{array}$ & $\begin{array}{c}0.3498 \\
(0.0153)\end{array}$ \\
\hline Asian & $\begin{array}{c}1.3156 \\
(0.2644)\end{array}$ & $\begin{array}{l}-0.0062 \\
(0.0288)\end{array}$ & $\begin{array}{c}0.0782 \\
(0.0452)\end{array}$ & $\begin{array}{c}0.1097 \\
(0.0399)\end{array}$ \\
\hline Other Race & $\begin{array}{l}-1.8766 \\
(0.2755)\end{array}$ & $\begin{array}{l}-0.0477 \\
(0.0300)\end{array}$ & $\begin{array}{c}0.3135 \\
(0.0444)\end{array}$ & $\begin{array}{c}0.2021 \\
(0.0417)\end{array}$ \\
\hline $\begin{array}{l}\text { Risk } \\
\text { Tolerance }\end{array}$ & $\begin{array}{c}0.2646 \\
(0.1841)\end{array}$ & $\begin{array}{c}0.0211 \\
(0.0200)\end{array}$ & $\begin{array}{c}0.1962 \\
(0.0306)\end{array}$ & $\begin{array}{c}0.1546 \\
(0.0279)\end{array}$ \\
\hline $\mathbf{N}$ & 11707 & 11707 & 8642 & 11561 \\
\hline R.M.s.E. & 2.9199 & 0.3181 & 0.4223 & 0.4387 \\
\hline R-squared & 0.1715 & 0.0236 & 0.1001 & 0.0734 \\
\hline $\begin{array}{l}\text { Incremental } \\
\text { R-squared }\end{array}$ & 0.0002 & 0.0001 & 0.0042 & 0.0025 \\
\hline Mean Dep.Var. & 12.0837 & 0.1173 & 0.2719 & 0.294 \\
\hline
\end{tabular}


Table 4 (continued)

\begin{tabular}{|c|c|c|c|c|}
\hline & $\begin{array}{c}\text { Iminigrant } \\
(i x)\end{array}$ & $\begin{array}{l}\text { Owns: } \\
(x)\end{array}$ & & \\
\hline Intercept & $\begin{array}{l}-0.0090 \\
(0.0238)\end{array}$ & $\begin{array}{c}0.7606 \\
(0.0369)\end{array}$ & & \\
\hline Age & $\begin{array}{c}0.0005 \\
(0.0004)\end{array}$ & $\begin{array}{c}0.0024 \\
(0.0006)\end{array}$ & & \\
\hline Male & $\begin{array}{l}-0.0076 \\
(0.0048)\end{array}$ & $\begin{array}{c}0.0184 \\
(0.0074)\end{array}$ & & \\
\hline Catholic & $\begin{array}{c}0.0547 \\
(0.0057)\end{array}$ & $\begin{array}{l}-0.0117 \\
(0.0088)\end{array}$ & & \\
\hline Jewish & $\begin{array}{c}0.0531 \\
(0.0179)\end{array}$ & $\begin{array}{l}-0.0422 \\
(0.0277)\end{array}$ & & \\
\hline $\begin{array}{l}\text { Other } \\
\text { Religion }\end{array}$ & $\begin{array}{c}0.0439 \\
(0.0088)\end{array}$ & $\begin{array}{l}-0.0394 \\
(0.0137)\end{array}$ & & \\
\hline Black & $\begin{array}{c}0.0161 \\
(0.0064)\end{array}$ & $\begin{array}{l}-0.2103 \\
(0.0099)\end{array}$ & & \\
\hline Hispanic & $\begin{array}{c}0.4664 \\
(0.0086)\end{array}$ & $\begin{array}{l}-0.2173 \\
(0.0133)\end{array}$ & & \\
\hline Asian & $\begin{array}{c}0.7879 \\
(0.0224)\end{array}$ & $\begin{array}{l}-0.1975 \\
(0.0347)\end{array}$ & & \\
\hline Other Race & $\begin{array}{l}-0.0207 \\
(0.0233)\end{array}$ & $\begin{array}{l}-0.2738 \\
(0.0361)\end{array}$ & & \\
\hline $\begin{array}{l}\text { Risk } \\
\text { Tolerance }\end{array}$ & $\begin{array}{c}0.0273 \\
(0.0156)\end{array}$ & $\begin{array}{l}-0.1526 \\
(0.0241)\end{array}$ & & \\
\hline $\mathbf{N}$ & 11707 & 11707 & & \\
\hline R.M.S.E. & 0.2475 & 0.3832 & & \\
\hline R-squared & 0.3031 & 0.0663 & & \\
\hline $\begin{array}{l}\text { Incremental } \\
\text { R-Squared }\end{array}$ & 0.0002 & 0.0002 & & \\
\hline Mean Dep.Var. & 0.0972 & 0.8046 & & \\
\hline
\end{tabular}


Table 5

Regression of Fractions of Financial Wealth

\begin{tabular}{|c|c|c|c|c|}
\hline & $\begin{array}{l}\text { stocks } \\
\text { (i) }\end{array}$ & $\begin{array}{l}\text { Bonds } \\
(i i)\end{array}$ & $\begin{array}{l}\text { Saving and } \\
\text { Checking } \\
\text { (iii) }\end{array}$ & $\begin{array}{c}\text { Treasury } \\
\text { Bills } \\
\text { (iv) }\end{array}$ \\
\hline Intercept & $\begin{array}{l}-0.4871 \\
(0.0699)\end{array}$ & $\begin{array}{l}-0.1485 \\
(0.0195)\end{array}$ & $\begin{array}{l}1.9047 \\
(0.0996)\end{array}$ & $\begin{array}{c}0.1338 \\
(0.0574)\end{array}$ \\
\hline Age & $\begin{array}{l}-0.0003 \\
(0.0007)\end{array}$ & $\begin{array}{c}0.0004 \\
(0.0002)\end{array}$ & $\begin{array}{l}-0.0014 \\
(0.0010)\end{array}$ & $\begin{array}{c}0.0006 \\
(0.0006)\end{array}$ \\
\hline Male & $\begin{array}{c}0.0222 \\
(0.0074)\end{array}$ & $\begin{array}{l}-0.0039 \\
(0.0020)\end{array}$ & $\begin{array}{c}0.0172 \\
(0.0105)\end{array}$ & $\begin{array}{l}-0.0067 \\
(0.0060)\end{array}$ \\
\hline Catholic & $\begin{array}{c}0.0047 \\
(0.0083)\end{array}$ & $\begin{array}{c}0.0024 \\
(0.0023)\end{array}$ & $\begin{array}{c}0.0058 \\
(0.0119)\end{array}$ & $\begin{array}{l}-0.0109 \\
(0.0068)\end{array}$ \\
\hline Jewish & $\begin{array}{c}0.0209 \\
(0.0246)\end{array}$ & $\begin{array}{l}0.0430 \\
(0.0069)\end{array}$ & $\begin{array}{l}-0.0881 \\
(0.0351)\end{array}$ & $\begin{array}{l}-0.0136 \\
(0.0202)\end{array}$ \\
\hline Other Religion & $\begin{array}{l}-0.0072 \\
(0.0129)\end{array}$ & $\begin{array}{l}-0.0013 \\
(0.0036)\end{array}$ & $\begin{array}{c}0.0483 \\
(0.0184)\end{array}$ & $\begin{array}{l}-0.0383 \\
(0.0106)\end{array}$ \\
\hline Black & $\begin{array}{l}-0.0242 \\
(0.0113)\end{array}$ & $\begin{array}{l}-0.0027 \\
(0.0031)\end{array}$ & $\begin{array}{c}0.1048 \\
(0.0161)\end{array}$ & $\begin{array}{c}0.0075 \\
(0.0093)\end{array}$ \\
\hline Hispanic & $\begin{array}{l}-0.0481 \\
(0.0166)\end{array}$ & $\begin{array}{l}-0.0039 \\
(0.0046)\end{array}$ & $\begin{array}{c}0.1798 \\
(0.0236)\end{array}$ & $\begin{array}{l}-0.0242 \\
(0.0136)\end{array}$ \\
\hline Asian & $\begin{array}{l}-0.0056 \\
(0.0312)\end{array}$ & $\begin{array}{c}0.0036 \\
(0.0087)\end{array}$ & $\begin{array}{c}0.0501 \\
(0.0445)\end{array}$ & $\begin{array}{c}0.0150 \\
(0.0257)\end{array}$ \\
\hline Other Race & $\begin{array}{l}-0.0333 \\
(0.0383)\end{array}$ & $\begin{array}{l}-0.0101 \\
(0.0107)\end{array}$ & $\begin{array}{l}-0.0505 \\
(0.0546)\end{array}$ & $\begin{array}{l}-0.0135 \\
(0.0315)\end{array}$ \\
\hline RT1 & $\begin{array}{c}0.0973 \\
(0.0287)\end{array}$ & $\begin{array}{c}0.0152 \\
(0.0080)\end{array}$ & $\begin{array}{l}-0.1282 \\
(0.0408)\end{array}$ & $\begin{array}{l}-0.0547 \\
(0.0236)\end{array}$ \\
\hline RT1 - RT2 & $\begin{array}{l}-0.0226 \\
(0.0271)\end{array}$ & $\begin{array}{l}-0.0096 \\
(0.0076)\end{array}$ & $\begin{array}{c}0.0178 \\
(0.0387)\end{array}$ & $\begin{array}{c}0.0501 \\
(0.0223)\end{array}$ \\
\hline Log Income & $\begin{array}{c}0.0162 \\
(0.0050)\end{array}$ & $\begin{array}{c}0.0046 \\
(0.0014)\end{array}$ & $\begin{array}{l}-0.0320 \\
(0.0072)\end{array}$ & $\begin{array}{l}-0.0175 \\
(0.0041)\end{array}$ \\
\hline Log Wealth & $\begin{array}{c}0.0372 \\
(0.0030)\end{array}$ & $\begin{array}{c}0.0073 \\
(0.0008)\end{array}$ & $\begin{array}{l}-0.0904 \\
(0.0043)\end{array}$ & $\begin{array}{c}0.0113 \\
(0.0025)\end{array}$ \\
\hline $\boldsymbol{N}$ & 5012 & 5012 & 5012 & 5012 \\
\hline R.M.S.E. & 0.2441 & 0.0683 & 0.3477 & 0.2007 \\
\hline R-squared & 0.0599 & 0.0396 & 0.1526 & 0.0129 \\
\hline $\begin{array}{l}\text { Incremental R- } \\
\text { squared }\end{array}$ & 0.0024 & 0.0007 & 0.002 & 0.0013 \\
\hline Mean Dep. Var. & 0.1401 & 0.0144 & 0.4164 & 0.0949 \\
\hline
\end{tabular}


Table 5 (continued)

\begin{tabular}{|c|c|c|c|c|}
\hline & $\begin{array}{l}\text { IRA's and } \\
\text { Keogh } \\
\text { (v) }\end{array}$ & $\begin{array}{l}\text { Other } \\
\text { Assets } \\
\text { (vi) }\end{array}$ & & \\
\hline Intercept & $\begin{array}{l}-0.4623 \\
(0.0892)\end{array}$ & $\begin{array}{c}0.0593 \\
(0.0614)\end{array}$ & & \\
\hline Age & $\begin{array}{c}0.0026 \\
(0.0009)\end{array}$ & $\begin{array}{l}-0.0020 \\
(0.0006)\end{array}$ & & \\
\hline Male & $\begin{array}{l}-0.0186 \\
(0.0094)\end{array}$ & $\begin{array}{l}-0.0102 \\
(0.0065)\end{array}$ & & \\
\hline Catholic & $\begin{array}{c}0.0093 \\
(0.0106)\end{array}$ & $\begin{array}{l}-0.0114 \\
(0.0073)\end{array}$ & & \\
\hline Jewish & $\begin{array}{l}-0.0017 \\
(0.0314)\end{array}$ & $\begin{array}{c}0.0395 \\
(0.0216)\end{array}$ & & \\
\hline Other Religion & $\begin{array}{l}-0.0179 \\
(0.0164)\end{array}$ & $\begin{array}{c}0.0165 \\
(0.0113)\end{array}$ & & \\
\hline Black & $\begin{array}{l}-0.0618 \\
(0.0144)\end{array}$ & $\begin{array}{l}-0.0235 \\
(0.0099)\end{array}$ & & \\
\hline Hispanic & $\begin{array}{l}-0.0914 \\
(0.0212)\end{array}$ & $\begin{array}{l}-0.0121 \\
(0.0146)\end{array}$ & & \\
\hline Asian & $\begin{array}{l}-0.0391 \\
(0.0399)\end{array}$ & $\begin{array}{l}-0.0241 \\
(0.0274)\end{array}$ & & \\
\hline Other Race & $\begin{array}{l}-0.0559 \\
(0.0489)\end{array}$ & $\begin{array}{c}0.1635 \\
(0.0337)\end{array}$ & & \\
\hline RT1 & $\begin{array}{l}-0.0059 \\
(0.0366)\end{array}$ & $\begin{array}{c}0.0764 \\
(0.0252)\end{array}$ & & \\
\hline RT1 - RT2 & $\begin{array}{c}0.0199 \\
(0.0347)\end{array}$ & $\begin{array}{l}-0.0556 \\
(0.0239)\end{array}$ & & \\
\hline Iog Incone & $\begin{array}{c}0.0263 \\
(0.0064)\end{array}$ & $\begin{array}{c}0.0023 \\
(0.0044)\end{array}$ & & \\
\hline Log Wealth & $\begin{array}{c}0.0254 \\
(0.0038)\end{array}$ & $\begin{array}{c}0.0091 \\
(0.0026)\end{array}$ & & \\
\hline $\mathbf{N}$ & 5012 & 5012 & & \\
\hline R.M.S.E. & 0.3116 & 0.2146 & & \\
\hline R-8quared & 0.0326 & 0.017 & & \\
\hline $\begin{array}{l}\text { Incremental R- } \\
\text { squared }\end{array}$ & 0.0001 & 0.002 & & \\
\hline Mean Dep. Var. & 0.2483 & 0.0857 & & \\
\hline
\end{tabular}


Table 7

Preferences Parameters for Consumption Paths (Experimental Module)

\begin{tabular}{|l|c|c|c|}
\hline Parameter & $\begin{array}{c}\text { Lower } \\
\text { Bound }\end{array}$ & $\begin{array}{c}\text { Upper } \\
\text { Bound }\end{array}$ & Midpoint \\
\hline $\begin{array}{l}\text { Intertemporal substitution } \\
\text { Elasticity }\end{array}$ & $\begin{array}{c}0.007 \\
(0.003)\end{array}$ & $\begin{array}{c}0.36 \\
(0.01)\end{array}$ & $\begin{array}{c}0.18 \\
(0.01)\end{array}$ \\
\hline $\begin{array}{l}\text { slope of Consumption at zero interest } \\
\text { rate (percent per year) }\end{array}$ & $\begin{array}{c}0.28 \\
(0.18)\end{array}$ & $\begin{array}{c}1.28 \\
(0.19)\end{array}$ & $\begin{array}{c}0.78 \\
(0.18)\end{array}$ \\
\hline
\end{tabular}

198 observations

Table 8

Risk Tolerance and Consumption Path Preferences

\begin{tabular}{|l|c|c|c|c|c|}
\hline Average Parameter & $I$ & $I I$ & III & IV & P-value \\
\hline $\begin{array}{l}\text { Intertemporal substitution } \\
\text { Elasticity }\end{array}$ & $\begin{array}{c}0.18 \\
(0.01)\end{array}$ & $\begin{array}{c}0.21 \\
(0.03)\end{array}$ & $\begin{array}{c}0.15 \\
(0.03)\end{array}$ & $\begin{array}{c}0.20 \\
(0.02)\end{array}$ & 0.28 \\
\hline $\begin{array}{l}\text { slope of Consumption at zero } \\
\text { interest rate (percent per } \\
\text { year) }\end{array}$ & $\begin{array}{c}0.80 \\
(0.23)\end{array}$ & $\begin{array}{c}1.10 \\
(0.60)\end{array}$ & $\begin{array}{c}0.53 \\
(0.60)\end{array}$ & $\begin{array}{c}0.53 \\
(0.50)\end{array}$ & 0.87 \\
\hline
\end{tabular}

198 observations 
Table 6

Risk Tolerance, Minimum Risk Tolerance, and Risk Aversion

6-A. A11 Respondents

\begin{tabular}{|l|c|c|}
\hline & Risk Tolerance & Risk Aversion \\
\hline Unweighted & 0.2391 & 12.1193 \\
& $(0.0013)$ & $(0.0482)$ \\
\hline Income-weighted & 0.2417 & 11.9928 \\
& $(0.0013)$ & $(0.0487)$ \\
\hline Wealth-weighted & 0.2441 & 11.9781 \\
& $(0.0014)$ & $(0.0486)$ \\
\hline
\end{tabular}

11,136 observations

6-B. All Respondents--Non-stock holders get zero risk tolerance

\begin{tabular}{|l|c|l|}
\hline & Risk Tolerance & \\
\hline Unweighted & $\begin{array}{c}0.0738 \\
(0.0013)\end{array}$ & \\
\hline Income-weighted & 0.1079 & \\
& $(0.0014)$ & \\
\hline Wealth-weighted & 0.1418 & \\
& $(0.0016)$ & \\
\hline
\end{tabular}

11,136 observations

6-C. stock holders only

\begin{tabular}{|l|c|c|}
\hline & Risk Tolerance & Risk Aversion \\
\hline Unweighted & $\begin{array}{c}0.2435 \\
(0.0025)\end{array}$ & $\begin{array}{l}11.8904 \\
(0.0888)\end{array}$ \\
\hline Income-weighted & 0.2480 & $\begin{array}{l}11.7279 \\
(0.0901)\end{array}$ \\
\hline Wealth-weighted & $0.0025)$ & 11.8346 \\
& 0.2485 & $(0.0895)$ \\
\hline
\end{tabular}

3,377 observations

Note: Table shows average (standard errors in parentheses) of rigk tolerance and risk aversion using the "mean" numerical weights to the 4 responses given in Table 1. 
Figure 1. Distribution of Preference Parameters

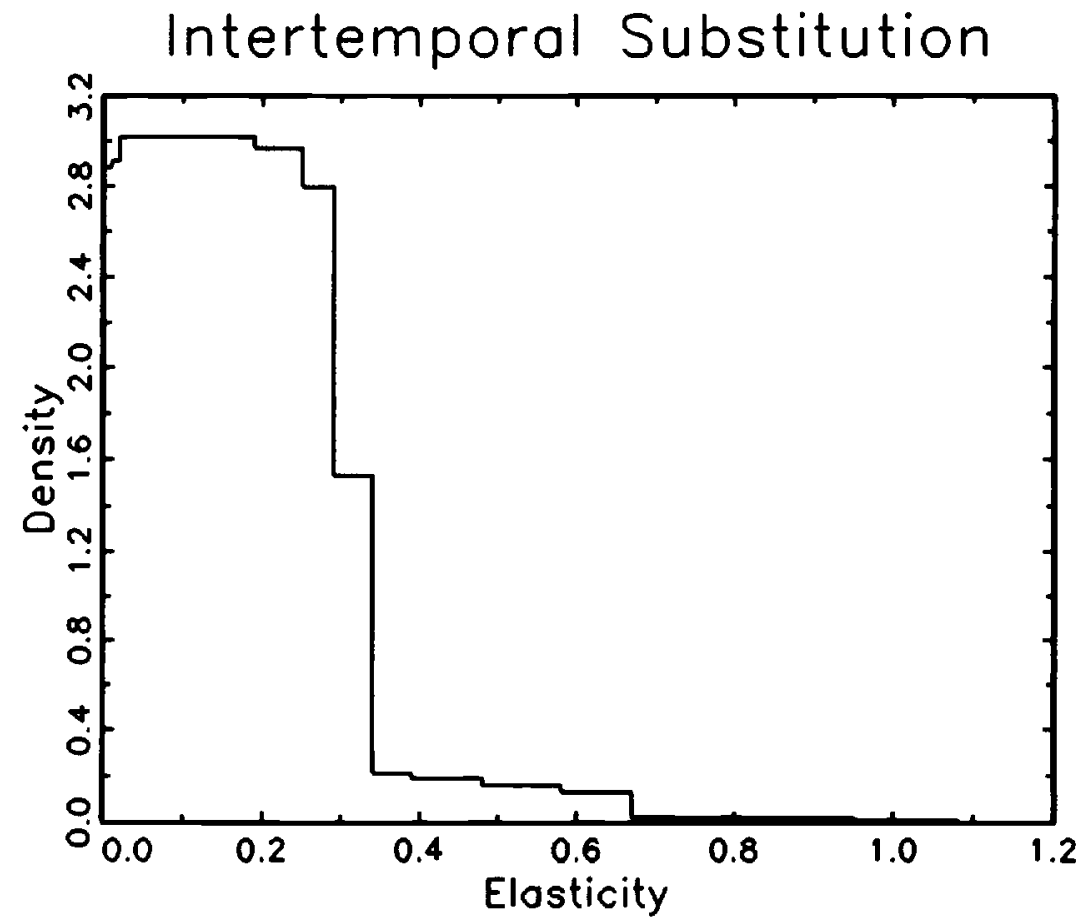

Time Preference

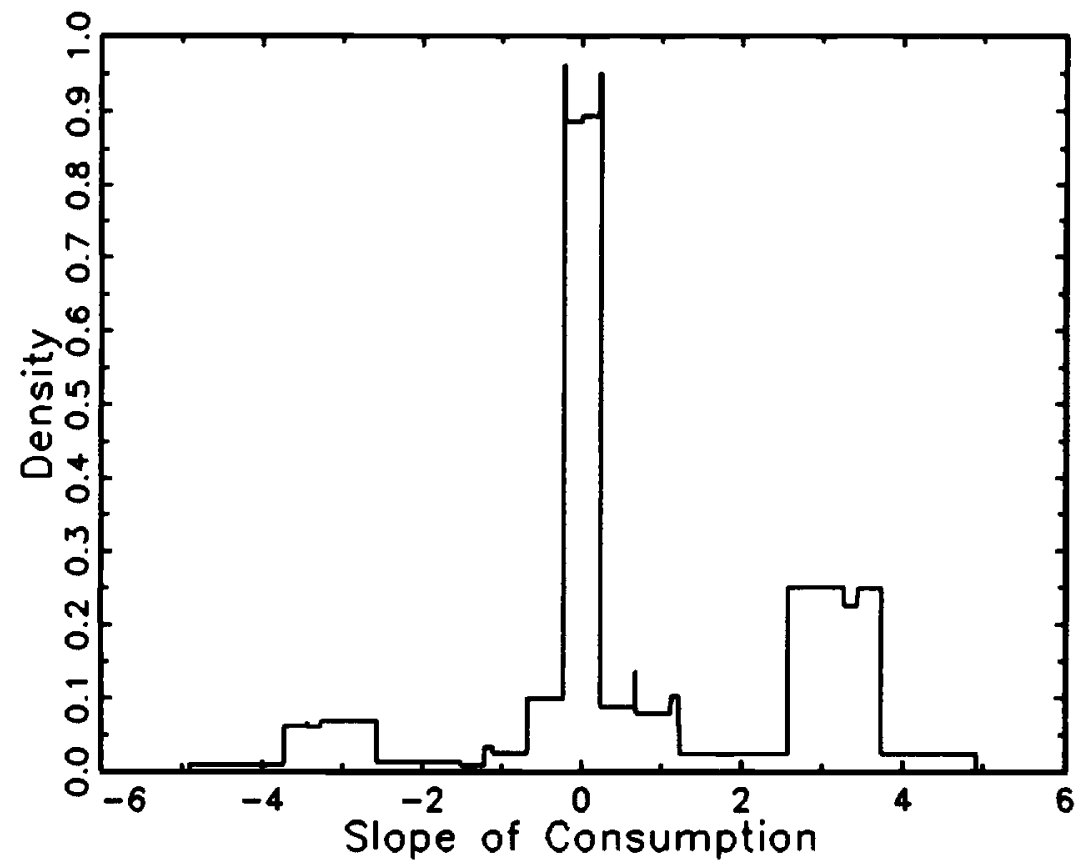


Release 3 Module K: Spending and Saving Preferences

KO.

EXACT TIME NOW:

Now I have a few questions about your preferences for spending and saving as you get older. To make the questions comparable for all respondents in the survey, let's suppose that you are now 50 years old, that you [and your (husband/wife)] will retire when you are 65, and that you [and your (husband/wife)] will live to be 80 . Further suppose that future health care costs are fully covered by insurance, that there will be no inflation, and that your income after taxes is guaranteed to be $\$ 3000$ each month from age 50 to age 80 .

R1. [GIVE CARD I TO R.] Card I contains several possible patterns of monthly spending before retirement, the striped bars, and after retirement, the solid black bars. By saving part of your income before retirement, you can have more to spend after retirement, as in choice $\mathrm{E}$. Or you could borrow and spend more before retirement, spending less and repaying the loan after retirement, as in choice A. Or you could just spend your income each month, as in choice C. Thus you can afford any of the spending patterns shown on Card $I$. Which pattern do you like the most?

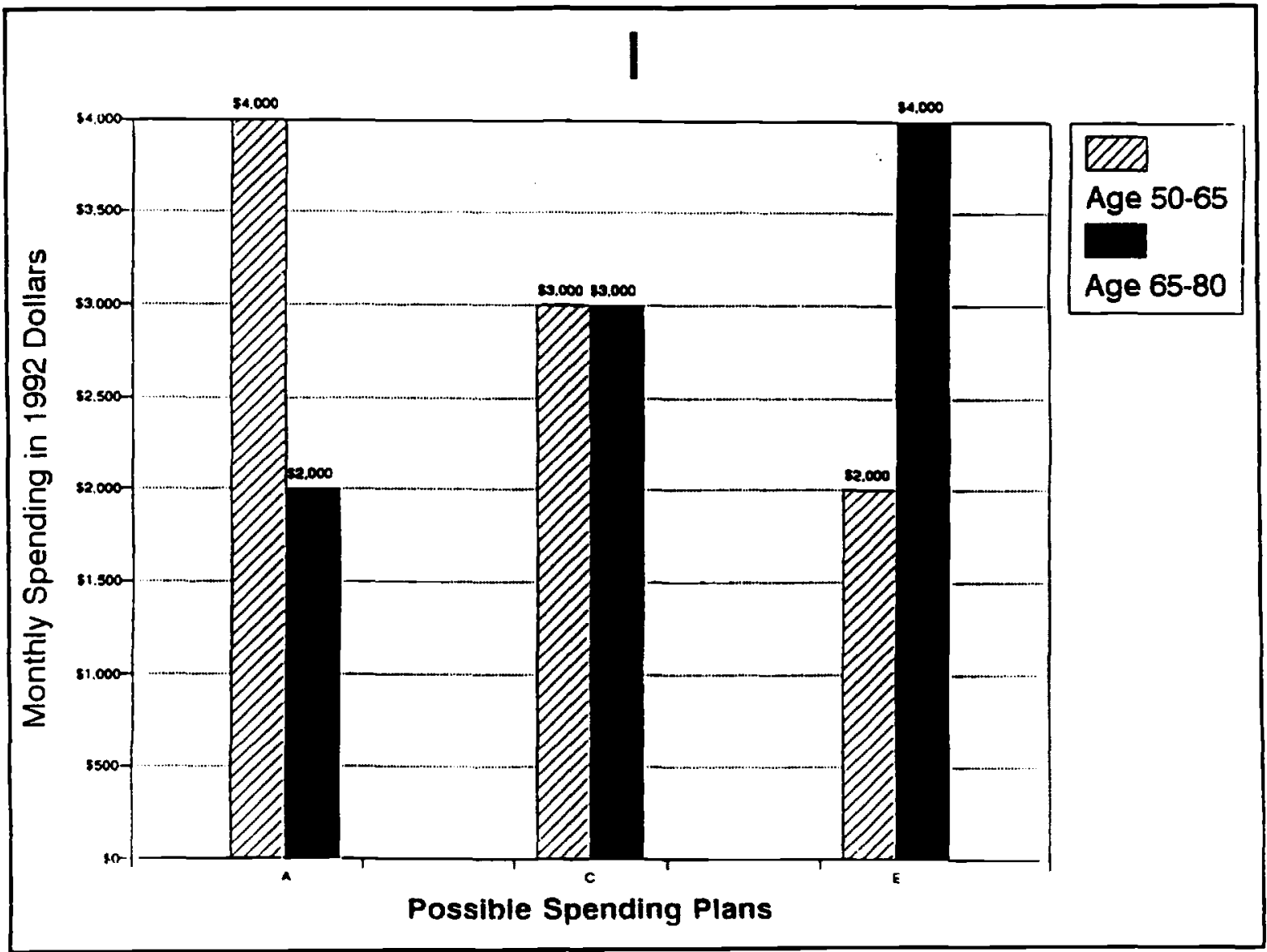
R CHOSE ALTERNATIVE:
A
c
E 
K2. [GIVE CARD II TO R.] Here are the same patterns as before, with two additional choices. Which do you prefer?
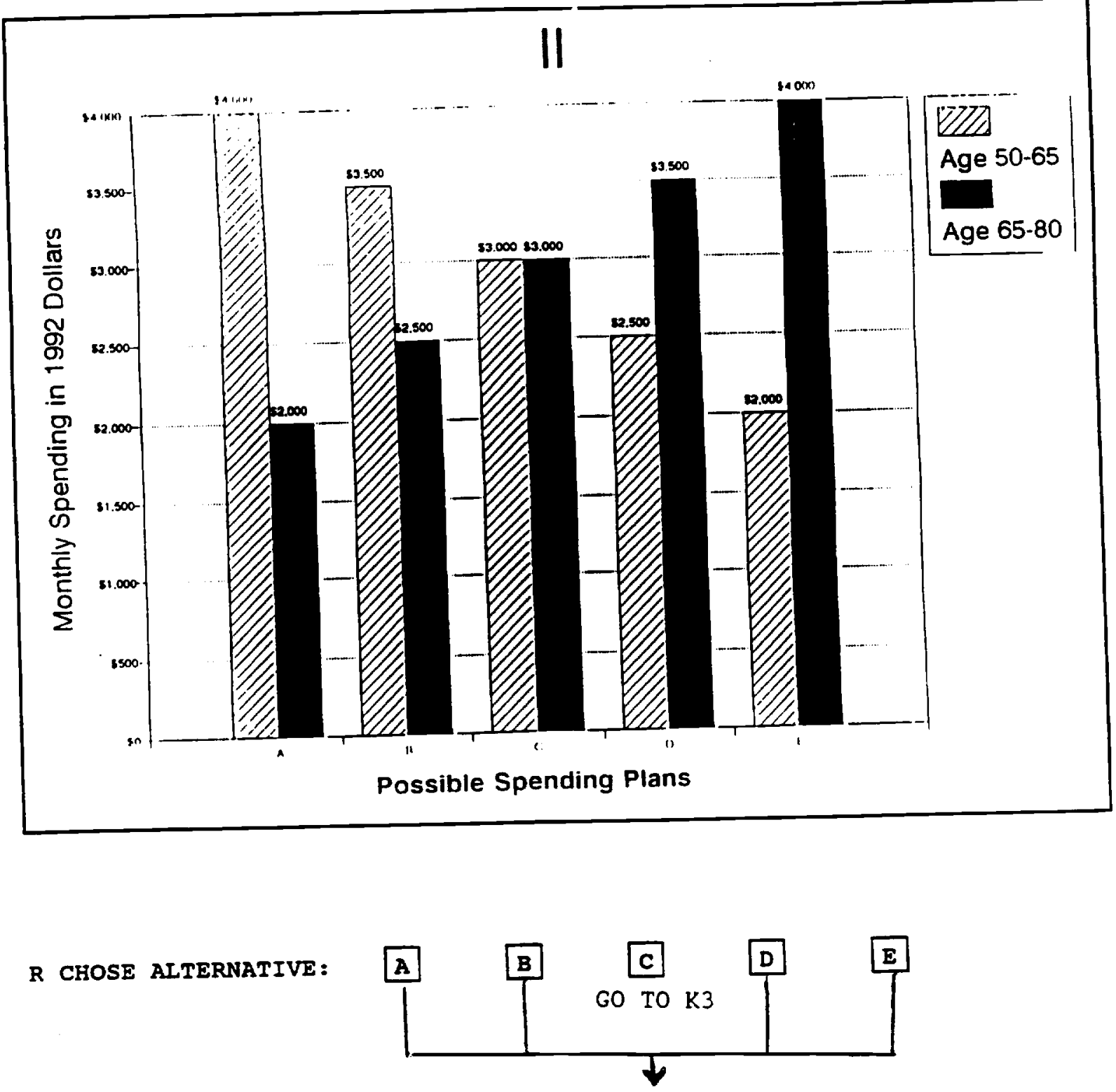

GO TO K4 
K3. GIVE CARD III TO THOSE WHO CHOSE ALTERNATIVE C, THEN SAY: Here is another card with 5 more choices that are fairly close to the one you just chose. Again, assume that you can afford any of the spending patterns shown on the card. which one do you prefer?

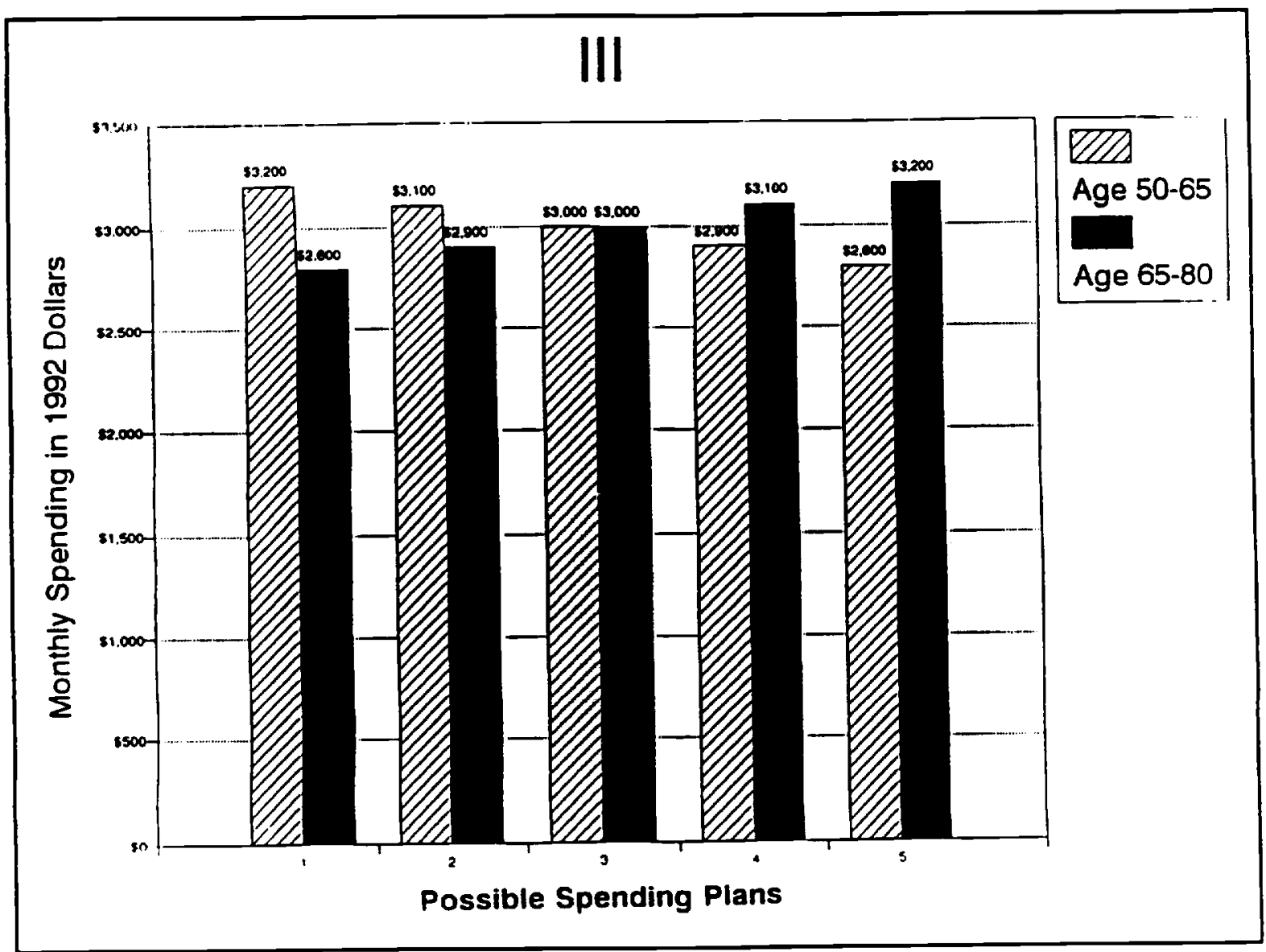

R CHOSE ALTERNATIVE

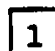

2

3

4

5 
K4. [GIVE CARD IV TO R.] Here is another card with 5 more spending patterns for before and after retirement. As before, by saving part of your income before retirement, you can have more to spend after retirement. Assuming that you can afford any of the spending patterns shown on Card IV, which pattern do you like the most?

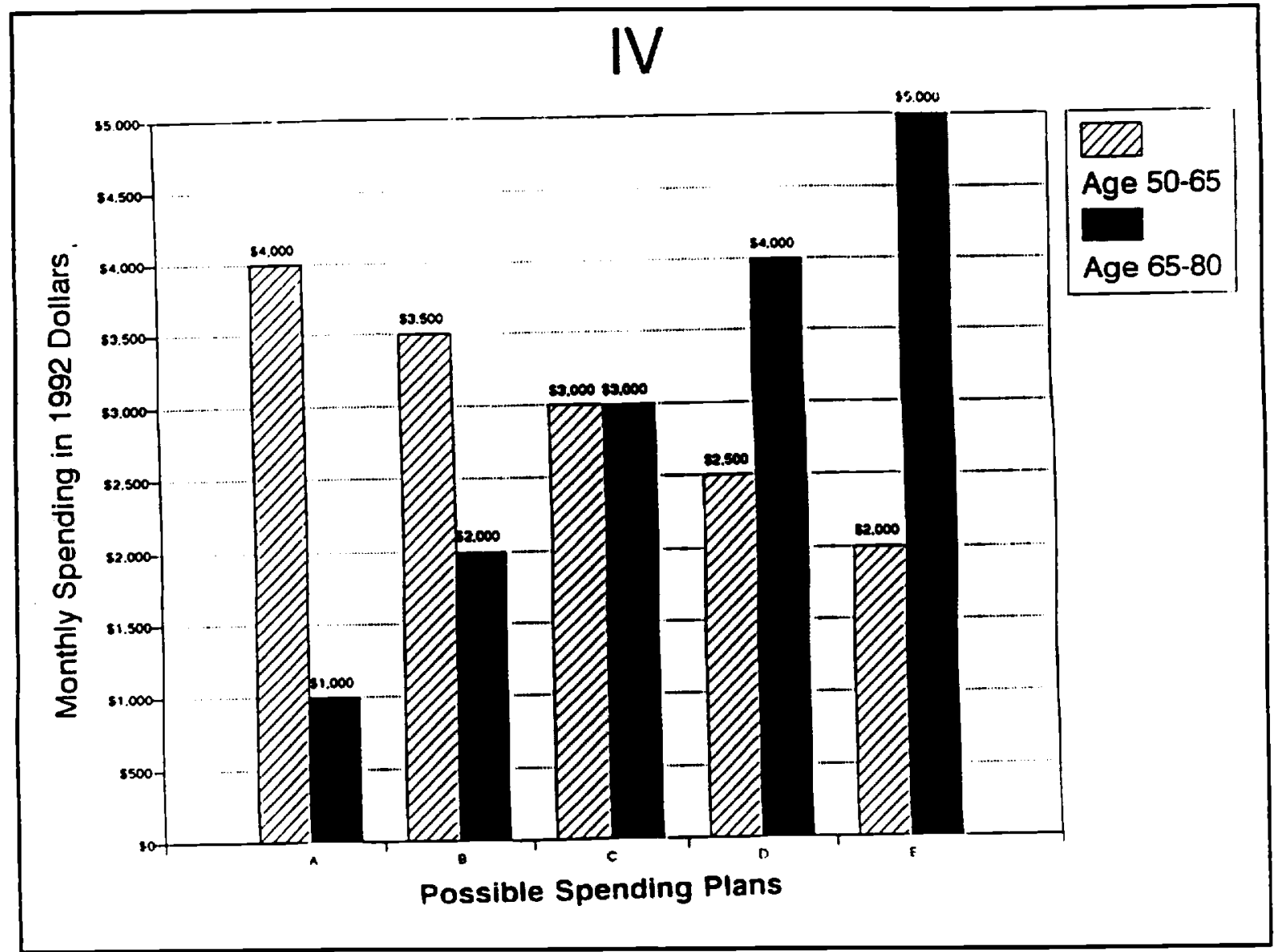
R CHOSE ALTERNATIVE:
A
B
c

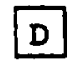
E 
R5. [GIVE CARD V TO R.] Finally, this is the last card with spending patterns. Which do you prefer?

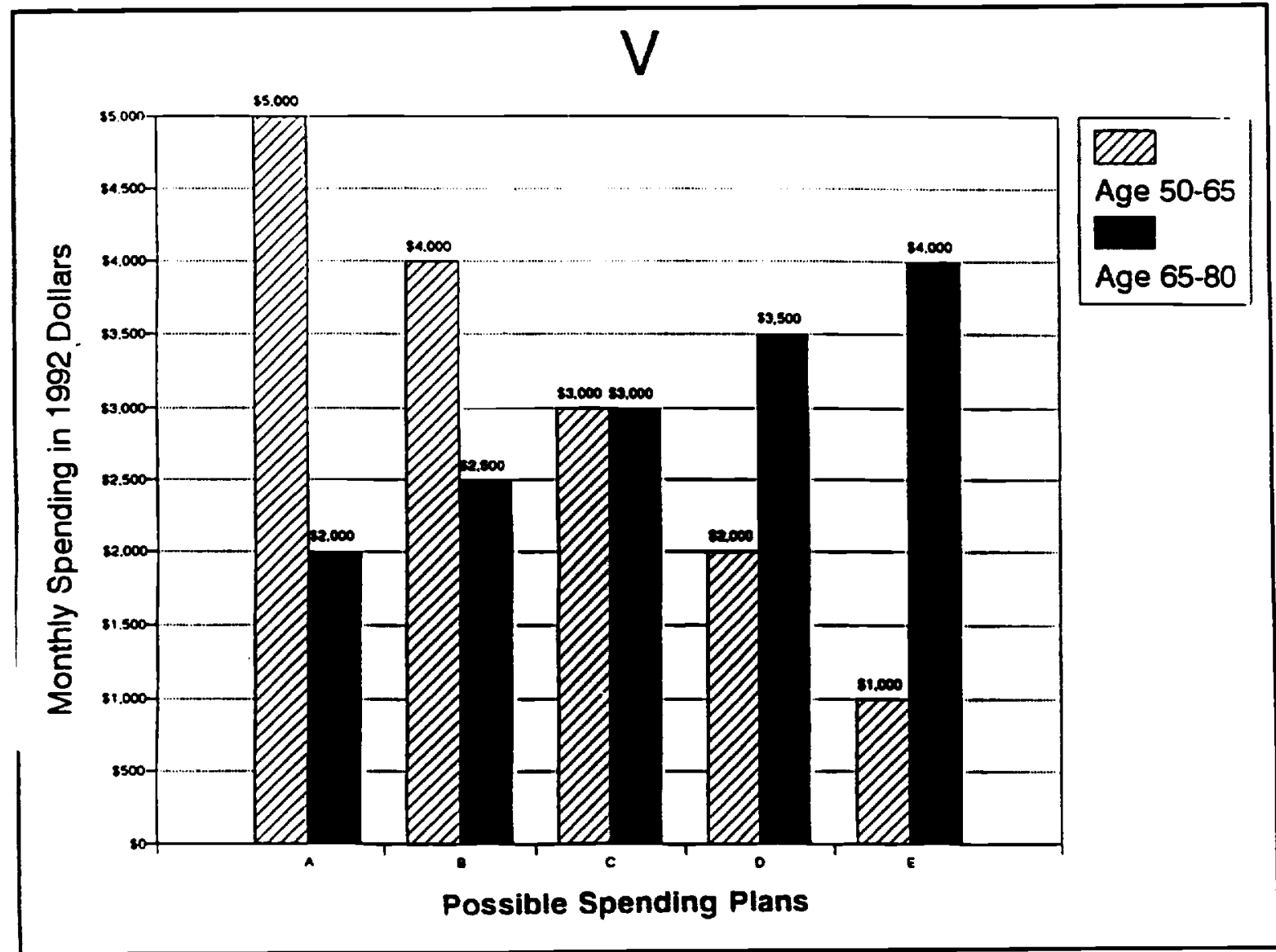

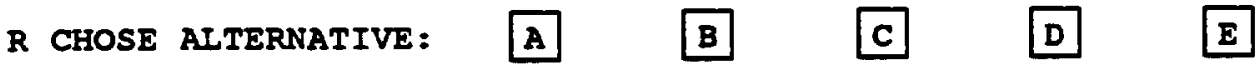

